\title{
国 \\ Market Timing of New Equity Offerings: Evidence from Chinese Listed Firms
}

\author{
Shiguang Ma ${ }^{1}$ and Subhrendu Rath ${ }^{2}$
}

\begin{abstract}
A well-established paradigm of the developed financial market is that firms take advantage of market valuations to make financial decisions. Do firms operating in a highly controlled market follow similar financial strategies? We find that the new equity offerings of Chinese listed firms are strongly associated with market valuations. However, the market timing effectiveness is relatively lower in the firms owned by the State and in the time when firms conduct non-tradable share reform by liquidating non-tradable shares. We also find that the proceeds from equity offerings are expended more in the form of opportunistic and discretionary usage than investment requirements. Our empirical evidence supports the general applicability of the equity market timing theory to the highly controlled emerging market of China.
\end{abstract}

JEL Classification: G30, G32

Keywords: Market timing, new equity offerings, state ownership, non-tradable shares reform, China.

\footnotetext{
${ }^{1}$ University of Wollongong, Wollongong, Australia, shiguang@uow.edu.au

${ }^{2}$ Curtin University, Perth, Australia

Acknowledgement: We would like to thank Lakshman Alles, Pat Fraser, Elaine Laing and participants at the Financial Markets and Corporate Governance conference (Wellington, 2014) and the Accounting and Finance Association of Australia and New Zealand (Perth, 2013) for helpful comments and suggestions.
} 


\section{Introduction}

The market timing of equity issuance is a special case where the sale of new shares is undertaken at times when the share price is high. According to Baker and Wurgler (2002), high market valuations are the first-order determinants of equity issuances and help explain capital structure adjustments of US firms. Primarily designed for a developed financial market such as the US, a key assumption behind the market timing arguments is that current high market valuations provide opportunities to issue equities at lower cost to the current shareholders. The empirical results of the timing theory by Baker and Wrugler (2002) and Welch (2004), among others, have been quite conclusive in this regard in the US where the firms are expected to follow the shareholder wealth maximisation principle.

In addition, a test of the market timing theory in an economic environment other than the US provides a robustness test for the empirical regularities observed for the US market. Mahajan and Tartaroglu (2008) find the evidence for market timing in G-7 countries to be mixed. Louhgran, Ritter and Rydqvist (1994) provide substantial evidence that market timing is a significant factor in IPOs, especially for countries in the region of emerging East Asian countries. Despite the controversy and importance of market timing as an alternate model to pecking order and trade-off theories of capital structure, investigation of market timing of equity offerings in non-US countries is still sparse. In particular, an investigation on market timing of equity offering in the largest emerging market of China is unlikely to be cited. This research intends to fill the void. We believe ours is among the precursory papers to undertake a comprehensive examination of the market-timing issue for the Chinese market.

In this paper we posit that the new equity offerings of Chinese listed firms are partly motivated by market timing issues. If the highly controlled emerging market is based without regard to equity market conditions, the new equity offerings should not correlate with timing opportunities. On the other hand, evidence of market timing by Chinse listed firms would mean that, similar to the firms in developed economies, the Chinese authorities and firms also take into account the market conditions and attempt to maximise the efficiency of equity offerings while raising capital. To the extent equity market timing represents opportunity of wealth transfer from minority and new shareholders to the current controlling shareholders, which would affirm the validity of shareholder wealth maximisation incentives even for the highly controlled emerging market of China.

Within the paradigm of shareholder wealth maximisation, transfer of wealth from minority shareholders to the controlling shareholders can take many forms. In the Chinese context, the share issuances and state ownership divestiture programs are either highly controlled or mainly mandated by government and therefore assumed to be independent of market conditions in some extent. Hence it is not clear that the shareholder wealth maximisation principle and the ensuing mechanism of equity timing would be applicable to a controlled economy such as China and as such presents an open empirical question.

The equity financing and its timing are important for firms of developed economy, which has been well addressed in literature (Baker \& Wrugler, 2002; Welch, 2004; Mahajan \& Tartaroglu 2008). In many respects, the Chinese financial market system serves as a counter example to established findings in corporate finance literature (Allen et al., 2005). Even though the market timing arguments suggest that managers should take advantage of favourable market conditions, the Chinese listed firms are greatly controlled to issue equity per se for the following reasons. First, new equity offering as a financing option is tightly 
controlled by the Chinese Securities and Regulatory Commission (CSRC) and is typically available to only a fraction of listed firms. For example, an application for secondary equity offering can only be made after 12 months of previous initial public offerings (IPOs) or secondary equity offerings (SEOs) and the applicants should have positive earnings prior to a SEO requiring further checks by the CSRC (Zou \& Xiao, 2006).

Second, due to political and social concerns, the Chinese government assists state owned enterprises (SOEs) in which it retains a large stake in securing bank loans rather than seeking external capital via equity (Tian \& Estrin, 2008). This is especially applicable in China where the banking industry is highly controlled and state owned. State controlled firms are likely to have better access to bank loans, thereby alleviating the need to raise equity. Also, the state ownership acts as a strategic control, due to concerns of dilution of state influence, when new equity is issued (Xu \& Wang, 1999). For these reasons, evidence of association between market valuation and new equity offerings would be a strong support for the proposition that market timing, in a manner similar to firms in developed markets, is also a powerful financing opportunity for state owners, even when there are no compelling reasons for the opportunity to be taken advantage of.

Finally, a significant market structure change may deter market timing effect. In particular, the change is due to seriously mandated policy that has been implemented in a short period. For example, before 2005, when a company went to public through initial public offering (IPOs), the state owned and legal person ownership were converted into shares that were nontradable in the secondary market. The share price of a firm with a large proportion of nontradable shares was usually distorted to represent its market value. Thus, China commenced non-tradable share reform from 2005, which required firms to liquidate their non-tradable shares in several scheduled years. Indeed, by the end of 2007 , nearly all state controlled firms that had non-tradable shares had completed the share reform and represented more than $97 \%$ of non-tradable shares.

Nevertheless, we find that overall market timing plays a significant role in capital structure changes of Chinese corporations. The findings in our study suggest that Chinese listed firms raised new equity capital through SEOs during periods of favourable market conditions when equity valuations were high. The historical market-to-book ratios, weighted by the firm's external equity financing (Baker \& Wrugler, 2002), have an inverse relationship with leverage and changes in Chinese listed firms. This relationship is robust to alternative weighting schemes. However, market timing is indeed disturbed by firms' ownership status and powerfully mandated policy. We find that market timing effectiveness is reduced when a firm is ownership controlled by state and in the period of non-tradable reform from 2005 to 2010. We also examine persistency and pervasiveness effect of market timing by investigating cumulative leverage changes for 3,5, 7 and 9 year periods after the IPOs. We find that the effectiveness of market timing is less persistent for state controlled firms in the years of their non-tradable share reform.

To obtain a deeper understanding of the motivations behind the decision of new equity issuance and its correlation with state ownership, we analyse the subsequent uses of proceeds from equity offerings by examining balance sheet and cash flow statement items that are designed to distinguish between investment and discretionary uses of capital from equity offerings. Our regression estimates imply that high state ownership SOEs spend substantial amounts of capital from equity raisings to pay down long-term debt and build up cash reserves - a finding that suggests equity offerings, coinciding with high market valuations, 
are primary sources of discretionary uses in years subsequent to the offerings. In contrast, we find that the low state ownership SOEs, as compared to the high state ownership group, allocate more funds from equity offerings towards investments, i.e., increase in capital expenditure and inventories.

The paper proceeds as follows. The next section (section 2) is institution background that highlights the regulatory framework, security issuance processes and state owned nontradable share reform. Section 3 lays out our data characteristics and variable constructions. Section 4 explains metrologies and provides relevant empirical analyses. Section 5 concludes this research.

\section{Institution background}

Beginning from December 1978, China initiated economic reforms in an attempt to establish a 'socialist market economy' through a market-oriented readjustment of economic policies to reshape the centrally-planned economy. The reform strategies focussed on the diversification of the state ownership system, introduction of foreign capital (and technology), and efficiency improvements of the SOEs. The initial economic reform resulted in an unprecedented boost in industrial productivity and outputs. Nonetheless, two critical obstacles to the economic development were the scarcity of capital and inefficient use of fund.

In order to address the issue of capital constraints in a state controlled economy, China's authority embarked on a series of market oriented reforms beginning with the opening of the Shanghai Stock Exchange in December 1990 and the Shenzhen Stock Exchange in April 1991. In early periods, the listed firms were mostly profitable assets from the SOEs which have been either carved out or spun off and restructured into independent legal entities for listing purpose. The government's primary aim in the establishment of stock markets was to seek additional external capital for the SOEs. Following listings, the state agencies maintained control of these firms as the state was usually the largest and controlling shareholder. However, over time, private firms (controlled by individuals and influential families) and other firms (such as controlled by collaborative entities or state agency representatives, which were termed as 'legal person' entities) were also allowed to list on the stock market.

As indicated above, a defining characteristic of reform associated with the Chinese stock market is that a proportion of outstanding shares of SOEs and legal person ownerships are non-tradeable in the secondary market. The original purpose for Chinese government to develop a stock market was to attract funds from society and promote SOEs operation efficiency rather than liquidating state owned assets. The designation of non-tradable shares could either maintain a large size of ownership or exercise indirect state control following the public listing of the firm. When a firm is listed on the market, the state and legal person ownership of assets (as they are incorporated into the listed entity) are represented as nontradable shares, while the shares sold to the public are designated to be tradable and allowed for trading on the secondary market. Since many of the legal person ownerships of shares are affiliated with SOEs, effective state control was enforced through the non-tradeable status of these shares. For example, takeovers or mergers involving firms with large chunks of nontradeable shares would require government permission for ownership transfer. If the firms issue stock dividends or conduct right issues, the newly received or subscribed shares by the state or state representative agencies will accrue without affecting the overall proportionality 
of state ownership and non-tradeable shares in the firm. Through these controls, the state had effective hold on the ownerships with ratios of non-tradable shares to total shares outstanding being $68.46 \%$ in $1997,64.49 \%$ in 2000 and $59.60 \%$ in 2004 . Nonetheless, following the nontradable share reform of 2005 , these controls have started to decrease in a substantial manner.

The effective control through state ownership combined with high proportions of nontradable shares engendered serious agency issues in these public firms. First, because the state is the 'permanent' controlling shareholders for many firms, the competitive discipline through the market for corporate control via mergers and takeovers was greatly diminished. In addition, the managerial skill sets of these firms, inherited from previous government structures, lacked the necessary corporate proficiencies impairing firms' capabilities to compete in the product market. Second, the non-tradability of a large portion of shares made capital restructuring of firms to be largely ineffective. Finally, the non-tradeable shares created an artificial premium on tradable shares available for circulation and created a 'discount' on the non-tradable shares ${ }^{3}$. Overall therefore, the equity prices were distorted and were not able to adequately signal changes in the supply and demand of equity capital.

The problem associated with non-tradeable shares became quite evident by the end of 1999 when the state attempted to circulate non-tradable shares and reduce the state ownership of publicly listed firms. In June 2001, the State Council promulgated "Temporary Provision to Reduce State Ownership and Ensure Social Security Fund". This provision stipulated that the SOEs should sell $10 \%$ of state shares to the public in their IPOs or SEOs, and the proceeds would be used for the newly constituted Social Security Fund. This provision had the indirect effect of diluting the price of tradable shares. Faced with investor backlash, the CSRC on behalf of the State Council abolished this provision by the end of 2001 .

In 2005, the Chinese government instituted a major reform of non-tradable shares through the CSRC's "Notice to Dispose Non-tradable Ownership of Listed Firms". The new reform involved provisions to protect the value of tradeable shares. First, the non-tradeable shareholders were required to compensate for the value dilution of existing tradable shares in the form of additional shares, cash or options. Second, to mitigate the possible adverse market reaction, the reformed non-tradable shares would have to be in a commensurate lockup period before they are allowed to trade on the secondary market. For example, if the reformed non-tradable shares are less than $5 \%$ of the outstanding shares, the shareholders are allowed to trade the reformed non-tradable shares on the market only after 12 months. Owners with large holdings of reformed non-tradable shares were allowed to trade less than $10 \%$ of the firm's ownership after 24 months and the full quantity after 36 months. Third, the CSRC scheduled the 2005 reform in batches to minimise its market effect. For instance, the first batch of four firms participated in the pilot program of reform in 2005; the second batch constituted of 42 firms until June 2005 and the third batch of another 35 large firms joined the reform by November 2005. By the end of 2007, nearly all state firms that had nontradable shares had completed the share reform and represented more than $97 \%$ of China's Ashare market capitalisation ( $\mathrm{Li}$ et al, 2011). As a result of these reforms, the average state ownership and non-tradable shares have significantly reduced from 2006 to 2010: from $30.31 \%$ to $9.31 \%$ for state ownership and from $50.01 \%$ to $18.36 \%$ for the non-tradeable shares.

\footnotetext{
${ }^{3}$ Chen and Xiong (2001) found that the average discount on non-tradable shares relative to their tradable counterparts is $77.93 \%$ and $85.59 \%$, respectively, based on auction and agreement transfers. Green (2003) estimates that the non-tradable shareholders were, on average, paid only a tenth of the market prices on their equity holdings.
} 
As the sole regulator of Chinese securities market, CSRC institutes policies and trading rules, monitors the market and participants, and controls the equity offerings. For example, the CSRC determines the sizes of new equity issuances of IPOs and SEOs each year based on the capacity of the capital market to absorb new shares. Through the stated objective to control supply of shares the CSRC attempts to artificially control the share price and avoid periodic market crashes that characterise developed share markets. In line with this objective, CSRC schedules a timetable of new listings each year and adjusts this timetable in terms of prevailing market conditions. For the SEOs, only right issues were allowed until the regulatory changes in 1998 which relaxed eligibility for SEOs. In order to carry out an SEO, a firm must meet time and accounting criteria. For example, a SEO should be after 12 months following the IPO or a prior SEO. The SEO firms should have positive earnings in past two years. These guidelines have been amended to the market condition (Zou \& Xiao, 2006) but the access to capital market is generally restricted.

Given the regulatory restrictions associated with capital raisings it was a preferable strategy for firms to issue small-scale IPOs to avoid large loss of under-pricing and then wait for a secondary issue later to take advantage of high valuations (Bo et al., 2011). In our untabulated results, we find that the total proceeds (rights and public offerings) of SEOs from 2007 to 2010 ranges from 101.85 to 299.56 billion RMB while the corresponding range during the previous seven years (2001 to 2006) is only between 19.31 to 64.66 billion RMB. The high market valuation period from 2007 to 2010 coincides with periods of active SEO through right issues and secondary public offerings. Prima facie, it may therefore appear as a common goal for the listing firms, underwriters and the CSRC to use the SEOs as an opportunity to maximise the pricing of new issues.

\section{Sample and variables}

\subsection{Sample description}

Our sample consists of firms listed on the Chinese stock markets during a sample period that spans from 2001 to 2010. The majority of our data are collected from the China Stock Market and Accounting Research Database (CSMAR) developed by the Shenzhen GTA Information Technology Company and the University of Hong Kong. We supplement this data from Shanghai Stock Exchange Statistical Annuals, Shenzhen Stock Exchange Fact Books and firms' annual reports wherever necessary.

The choice of the sample period (2001 to 2010) is due to the following considerations. First, although the economic reform in China had seen the establishment of stock markets prior to 2001, and the government's intention to reduce state ownership of SOEs was announced in 1994 and again in 1999, however, the state ownership reduction through non-tradable share liquidation was formally considered in earnest from 2001. The impetus for state agencies to divest shares came only after the Ministry of Treasury decided to implement a Social Security Fund in 2001 (Ding \& Graham, 2007). Second, the regulations concerning security issuance were not as established and settled as they were after 2001. Due to the uncertainty in regulation and the nature of stock trading in an emerging and highly controlled economy, the initial years of the development of the financial market created a supplier's market with firms having artificially extreme market-to-book ratios. Finally, prior to 2000, the number of firms with available accounting information is too few in our dataset to conduct required 
analyses. Thus, the observations in selected sample period satisfy our investigation of market timing for both secondary equity issuance and state ownership reduction.

Because many Chinese listed firms were either carved out or spun off from existing SOEs, these firms were not independent entities before their IPOs and their pre-IPO data cannot be tracked. Thus, our investigation focuses on market timing of new equity offerings of listed firms after their IPOs. The new equity offerings of a listed firm is also defined as secondary equity offerings or seasoned equity offerings (SEOs), thus we will use SEOs for new equity offerings alternatively at convenience. Due to the above consideration, our sample construction is a modified version of the procedure used by Baker and Wurgler (2002). Baker and Wurgler's sample consists of observations that track firms from their pre-IPOs to the time they cease to exist in the sample. Their market timing on equity issuance consists of IPOs and SEOs. In our sample, if a firm's IPO occurs during the sample period, we include observations from the first fiscal year after IPO to the last year it appears in the sample or 2010, whichever is later. If a firm's IPO occurs before the sample period, the firm-year observation begins from 2001. We include firms which had their IPOs prior to or after 2001, with their post-2001 accounting and security issuance data in our sample, since our primary motivation is to understand the new equity issuance of listed firms. This inclusion provided us with adequate sample sizes for our annual regression analyses.

As is practice in studies of leverages, we remove financial firms from our sample as they are subject to special regulation and have special leverage characteristics. We eliminate firms with cross-listings in a stock exchange other than the Shanghai or Shenzhen stock exchanges to avoid biases in our inferences from a sample that may contain firms having access to capital sourced outside of China. We also exclude firms classified by the CSRC as either "special treatment" (ST) or "particular treatment" (PT) firms. The CSRC classifies firms as ST or PT if they have experienced negative profit for two and three consecutive years, respectively, and imposes additional restrictions on new equity financing. The firms with incomplete, erroneous (e.g. book debt ratio greater than one) are also removed. Our final sample consists of 10,299 firm-year observations.

\subsection{Variables}

We follow Fama and French (2000) definitions of accounting variables, as used in Baker and Wurgler (2002), and make necessary adjustment in terms of the Chinese data characteristics. We define book debt $(D)$ as the difference between total assets $(T A)$ and book equity. The book equity $(E)$ is defined as total assets minus total liabilities and preferred stock plus deferred taxes. The market value of total assets is total assets minus book equity plus market equity, while the market equity is the total number of common shares outstanding multiplied by year-end market prices. Leverage $(D / T A)$ is either book or market leverage. Book leverage is debt divided by total asset and market leverage is debt divided by market value of total assets. As in Baker and Wurgler (2002), we drop firm-year observations where the book leverages are larger than one. Net equity issue $(e / T A)$ is the change in book equity minus the change in retained earnings divided by total assets. $\triangle R E / T A$ is the change in retained earnings divided by total assets. Net debt issue $(d / T A)$ is the residual change in assets divided by total assets.

Our measure of market timing comes from Baker and Wurgler (2002). The innovative feature of Baker and Wurgler's measure is the construction of a historical market-to-book ratio weighted by proportion of equity raisings. By weighting the market valuations with 
proportions of equity that has been raised up to time $t$, it captures the timing effect of equity offerings at precisely the points at which the valuations are high. The historical market-tobook ratio is computed/named as the external finance weighted average market-to-book ratio $(E F W A M B)$ and is

$$
\text { EFWAMB }_{t-1}=\sum_{s=1}^{t-1} \frac{e_{s}+d_{s}}{\sum_{r=1}^{t-1}\left(e_{r}+d_{r}\right)} \cdot(M / B)_{s}
$$

The $E F W A M B_{t-1}$ of a firm is calculated for each firm-year (denoted by 's') starting from the chronological year (denoted by 'r') the firm appears in the sample up to the year $t-1 . e$ and $d$ represent the net equity issue and net debt issue as defined earlier. Baker and Wurgler set the negative weights to be zero and drop the firm-year observations where the EFWAMBt-1 exceeds 10. Mahajan and Tartaroglu (2008) set the negative weights to be zero and maximum value of $E F W A M B_{t-1}$ to be 10 . Considering the high volatility of Chinese market and to retain adequate number of observations, we set the negative weights to be zero and maximum value of $E F W A M B_{t-1}$ to be 12 . The Baker and Wurgler (2002) measure of market timing $(E F W A M B)$, a combination of historical equity financing and historical $M / B$ ratio, is weighted by past values making the movements of $E F W A M B$ over time. A notable feature of Baker and Wurgler 's $E F W A M B$ measure is that it gives more weight to equity financing when $M / B$ high. Thus, large $E F W A M B$ represents market timing on equity offerings.

The cross sectional variables uses in regressions are as follows. Tangibility is represented by net property, plant and equipment over total assets (PPE/TA). Profitability is measured as earnings before interest, taxes, depreciation and amortization divided by total assets (EBITDA/TA). Size is logarithm of sales (LogSale). State ownership ratio (StateRatio) is the number of shares owned by state divided by total number of shares outstanding. Tradable share ratio (TradeRatio) is the number of tradable shares divided by total number of shares outstanding. State control dummy (State) is 1 if the state ownership is greater than $30 \%$ and the state is the largest owner of the firm, otherwise codes zero ${ }^{4}$. Non-tradable shares reform dummy (ReformD) codes 1 for the years during which a firm commenced non-tradable share reform to end of its reform completion, otherwise is zero. We winsorize ratio variables at their $99 \%$ and $1 \%$ levels to mitigate the effect of outliers.

\section{Methodologies and empirical analyses}

\subsection{Leverage change, market-to-book ratios and EFWAMB}

The distributions of the cross-sectional variables designed for this study are presented in Table 1 (Tables appear at the end of this article). The average and median book and market leverages are around 50\% and 30\%, respectively. These estimates are similar to estimates found in studies of Chinese stock markets during this period (e.g. Qian et al., 2009). The mean market-to-book ratio is 2.1638 with the lower fifth percentile being close to one (i.e., 0.9849) which indicates the general level of high market valuations for most of the firms during this period. While this evidence supports the overall growth-induced developing market outlook for the Chinese economy, the fact that high market-to-book ratios were pervasive it also points to possible overvaluation and mispricing during this period. For our

\footnotetext{
${ }^{4} 30 \%$ ownership level is the criterion for effective control set by the CSRC in "Notice on Issuing 'Guides to Constitutions of Listed Companies"”, December 16, 1997 (in Chinese, translated by the authors).
} 
ownership and control related variables, the average and median values of StateRatio are around $25 \%$. Our sample also includes firms having completed the non-tradeable share reform with the state ownerships being completely divested or the private firms without any state ownership. The average proportion of tradeable shares (TradeRatio) during the sample period is $55.58 \%$ indicating that close to $45 \%$ of shares on average were restricted from trading under the original imposed regulation, which is the target to be eliminated in the nontradable reform.

Table 2 summarises the annual leverage and financing behaviour for our sample by calendar years. Over the sample years, the market leverage shows more variation as compared to book leverage. This variation reflects the overall market condition prevalent during this period. For example, the sharp increase of market leverage from $21.0 \%$ in 2007 to $38.88 \%$ in 2008 is a concomitant result of the market bubble in 2007 and subsequently slowdown due to the global financial crisis of 2008, which is in line with the contraction of global equity markets. The sources of financing show no discernible pattern over calendar time. However, the calendar wise proportions of debt financing appear to higher than the equity financing proportions. As Baker and Wurgler (2002) note, the comparison of the levels of debt versus equity financing can be misleading in calendar-time aggregates 5 . Hence we carry out the detailed cross sectional analyses later in the paper.

In order to verify the effects of market conditions on financing decisions, we make a preliminary analysis of market-timing related variables on a calendar time basis. Since market timing hypothesis is based on the equity valuation (or misevaluation), both at the firm and aggregate levels, patterns of equity market movements should to be closely related to firm level market timing characteristics. Table 3 presents a year-wise movement of two equity market indices (Shanghai and Shenzhen composites) along with two firm level timing variables $(M / B$ and $E F W A M B)$ and two ownership related variables (StateRatio and TradeRatio).

There are several evidences of note in Table 3. The first evidence is that the average $M / B$, not unsurprisingly, closely tracks the movement of the broader market indices. For example, the peak of the $M / B$ ratio value (3.1125) occurs in 2007, the same year as the peaks of market indices. Further, the average $M / B$ closely follows the general year to year pattern of the market indices. The second point to note is that the Baker and Wurgler (2002) measure of market timing $(E F W A M B)$, a combination of historical equity financing and historical $M / B$ ratio, is weighted by past values making the movements of $E F W A M B$ over time slow to change. A notable feature of Baker and Wurgler's $E F W A M B$ measure is that it gives more weight to equity financing when $M / B$ high. This is indeed the case in Table 3 . The $E F W A M B$ changes very little and shows a gradual decline from 2001 to 2006 However, EFWAMB increases sharply in 2007 and remains high until 2010, even though the equity market drops off after 2007.

The fact that $E F W A M B$ stays high after 2007 can be attributed to the property of this weighted historical market-to-book ratio measure in that the large historical equity financing effects will persist into future $E F W A M B$ measures. Nonetheless, the EFWAMB can also be

\footnotetext{
5 "The table shows that on average, following the IPO, the annual change in assets is driven roughly 50 percent by net debt issues, 35 percent by net equity issues, and 15 percent by newly retained earnings. This is a broad generalization that hides wide cross-sectional variation, however, and indeed the change in assets is often negative." Baker and Wurgler, 2002, p. 7.
} 
driven by a recent-period equity financing activity if they are significantly large. In this paper, we conjecture that the state's desire to liquidate non-tradable shares and decrease state ownership happens in conjunction with equity financings which, in turn, is partly motivated by high market-to-book ratios. We see partial evidence of this in the next two columns (labelled StateRatio and TradeRatio.) The StateRatio shows steady decline from 2005 to 2010. Although this decline is gradual, the ownership level changes quite significantly from $23.53 \%$ in 2008 to $13.04 \%$ in 2009 and $9.34 \%$ in 2010 . Correspondingly, the TradeRatio, the measure of the proportion of non-restricted shares allowed for trading, steadily increases over the time. However it is possible that the mandated non-tradable reform could depress the market and affect the EFWAMB estimates of the firms that have both SEOs and non-table share liquidation. Untangling the market-timing motivation and non-tradable share reform is a major objective of our paper, and we provide further evidence of it in our cross sectional analysis.

\subsection{Sources of changes in leverage}

The first step in our analysis is the effect of market-to-book ratio on changes in leverage. Firms with high market-to-book ratio are likely to be high-growth firms and their capital needs may be funded from either debt or equity. We examine the association of the sources of annual financing needs to market-to-book ratio by decomposing the leverage change. Following Baker and Wurgler (2002), the annual changes in book leverage can be decomposed as follows:

$$
\left(\frac{D}{T A}\right)_{t}-\left(\frac{D}{T A}\right)_{t-1}=-\left(\frac{e}{T A}\right)_{t}-\left(\frac{\Delta R E}{T A}\right)_{t}-\left[E_{t-1}\left(\frac{1}{T A_{t}}-\frac{1}{T A_{t-1}}\right)\right]
$$

In equation (2), the change in leverage has three components: change in net equity issues $(e / T A) t$, change in retained earnings $(\triangle R E / T A) t$ and the residual change in leverage $\left[\left(E_{t^{-}}\right.\right.$ 1) $\left.\left(1 / T A_{t-1}-1 / T A_{t-1}\right)\right]$, which depends on the asset growth. This decomposition follows the accounting identity of changes in the growth of assets must be equivalent to changes in liabilities. We regress each of the three components and the total change in leverage on the market-to-book ratio and four other independent variables. We use three control variables that are shown to be reliably related to changes in the leverage in its cross section in several developed countries (Rajan \& Zingales, 1995; Mahajan \& Tartaroglu, 2007). They are the lagged values of asset tangibility (PPE/TA), profitability (EBITDA/TA) and firm size (LogSales). Since leverage is bounded by zero and one, the leverage is likely to revert towards mean when it is close to these boundaries, regardless of the effects of other variables. Therefore, we also include a lagged leverage (D/TA) to control for the mean reversion (Chen $\&$ Zhao, 2007; Chang \& Dasgupta, 2009). The regression takes the form:

$$
\begin{aligned}
& \quad\left(\frac{D}{T A}\right)_{t}-\left(\frac{D}{T A}\right)_{t-1}=\alpha++\beta_{2}\left(\frac{M}{B}\right)_{t-1}+\beta_{3}\left(\left(\frac{P P E}{T A}\right)_{t-1}+\beta_{4}\left(\frac{E B I T D A}{T A}\right)_{t-1}\right. \\
& +\beta_{5} \log (\text { Sales })_{t-1}+\beta_{6}\left(\frac{D}{T A}\right)_{t-1}+e_{t}
\end{aligned}
$$

We also include the current market-to-book ratio in the form of $M / B_{t-1}$ in the regression specification. The inclusion of $M / B_{t-1}$ is an important feature of the empirical method of (Baker and Wurgler, 2002). $M / B_{t-1}$ captures the immediate or current cross sectional effects of the market-to-book ratio on leverage can be attributed to current high growth opportunity and is isolated from its historical values. 
Table 4 summarises the results of regressions in equation (3) related to equation (2). The results most likely have the similar explanation to that of Baker and Wurgler (2002). The first regression specification in Table 4 is the effects on overall change in leverage and the other specifications are based on the components of change in leverage. The results indicate that the effect of the market-to-book ratio is strongest when it is associated with the net equity financing component. The coefficient of the market-to-book ratio in regression 2 of Table 4 is -0.0064 (significant at the one per cent level) and more in magnitude than the coefficients in specifications 3 or 4 in its absolute value. Note that the entered sign on each of the sources of financing (dependent variables) of regression specification are negative, thus making the implied association to be positive (negative) when independent variables are negative (positive). In general, the estimates for the four Rajan and Zingales (1995) variables are consistent with prior results in the Chinese market (Qian et al., 2009). This finding of strong positive association between market-to-book ratio and leverage change, nonetheless, is consistent with the notion that the equity market timing attempts may be at work in Chinese capital markets during our sample period.

Interestingly, the effect of market-to-book ratio is also positively related to changes in leverage due to changes in retained earnings (specification 3 ). This could be due to the ability of the market-to-book ratio to forecast future earnings (Baker \& Wurgler, 2002). The positive association of current market-to-book ratio $\left(M / B_{t-1}\right)$ and leverage changes through equity financing implies that equity market timing may have a role in it, at least in the short run. Next we explore the market timing further by using the historical market-to-book ratios (as measured by $E F W A M B_{t-1}$ ) and examine whether historical market valuations combined with non-tradable share reform and state ownership control can help explain changes in leverage ratios.

\subsection{Historical market-to-book ratios and market timing}

To take the historical market valuations into account for testing market timing in new equity issuance and the effects of state ownership control and non-tradable share reform on the market timing we take the form of regression:

$$
\begin{aligned}
\left(\frac{D}{T A}\right)_{t}=\alpha & +\beta_{1} E F W A M B_{t-1}+\beta_{2} E F W A M B_{t-1} * \text { factor }+\beta_{3}\left(\frac{M}{B}\right)_{t-1}+\beta_{4}\left(\left(\frac{P P E}{T A}\right)_{t-1}\right. \\
& +\beta_{5}\left(\frac{E B I T D A}{T A}\right)_{t-1}+\beta_{6} \log (\text { Sales })_{t-1} \\
& +\beta_{7}\left(\frac{D}{T A}\right)_{t-1}+e_{t}
\end{aligned}
$$

The presence of EFWMBAt-1 therefore measures the historical (and residual) effects of the market-to-book ratios on leverage. If the market timing explanations are to be persuasive, the historical market-to-book ratio $\left(E F W M B A_{t-1}\right)$ should have a stronger and negative effect on leverage. The evidence of concurrent downward changes in leverage, which are correlated with high historical market-to-book ratios, confirms the powerful pull of equity timing opportunities (as documented by Baker \& Wurgler, 2002). EFWMBAt-1*factor is an interaction variable in which factor represents either state ownership control or non-tradable share reform statue. It can be Statet-1 that is a binary variable equal to 1 if the state is the largest owner of the firm and the state ownership is larger than $30 \%$, otherwise is zero. The state controlling and large ownership implies that state firms have advantage in debt financing by access to more bank loan, which may alleviate their initiative in marketing 
timing of SOEs. Alternatively, the factor can be ReformD that is a binary variable equal to 1 for the years when a firm started non-tradable share reform to end of completion, otherwise is zero. The significant and negative coefficient of $E F W M B A_{t-1} *$ ReformD is also an evidence of market timing for liquidating non-tradable shares. The dependent variable of leverage ratio can be calculated in either market value or book value. Consistent results of regression on these two types of leverages would be strong evidence of market timing.

Table 5 shows the results for the Fama-Macbeth regression of annual leverages with equation 4. For an investigation in market timing on new equity offerings only we exclude interaction variable in regressions 1 and 3. It can be seen that the coefficients of $E F W A M B$ are negative in all regressions. Regardless of whether the leverage is measured as book or market, the historical market-to-book ratio has the net effect of reducing leverage. For example, a one standard deviation increase in the weighted average market-to-book ratio (from Table 1) is associated with $2.77 \%$ change in book leverage (regression 1 in Table 5). This evidence of the negative relationship between historical market-to-book ratio and leverage supports the notion that market timing is an important mechanism through which Chinese listed firms conduct new equity offerings and thus seek to alter their leverages.

Table 5 also shows that the state ownership control and non-tradable share reform policies adopted in China distort the effectiveness of market timing in SEOs. The coefficients of the interaction variable $\left(E F W A M B *\right.$ State $\left._{t-1}\right)$ are negative with values of -0.0031 and -0.0004 in book leverage and market leverage regressions (regressions 2 and 4) respectively. They are quite smaller in absolute values than the coefficients of EFWAMB -0.0097 and -0.0135, with the significance down from $1 \%$ to $10 \%$ level. This evidence supports our conjecture that state controlled firms are likely to have better to access bank loans, because majority of large banks in China are owned by state. The advantage to access bank loans alleviates SOEs' initiative and effectiveness in SEOs by timing the market.

The coefficients of interaction variable $E F W A M B *$ ReformD are -0.0044 and -0.0064 at $10 \%$ significance in book leverage and market leverage regressions (regressions 3 and 6), respectively. In comparison with the coefficients of EFWAMB -0.0120 and -0.0115 at $1 \%$ significance, both the absolute magnitude and the significance of the EFWAMB*ReformD coefficients are quite smaller. This result shows that the firms have less effectiveness to timing the market for their SEOs in their non-tradable reform years. Non-tradable share reform through liquidating non-tradable shares is mandatory as promulgated by the CSRC, which must be completed by the designated firms in a short period, such as two or three years. Although market timing is initiated at both government and firms' levels, the market timing in liquidating non-tradable shares should be less likely observed. Non-tradable share reform implies that more shares will be circulated on the market and thus that depresses the market price of tradable shares. The firms in their non-tradable shares reform periods cannot time the market for their SEOs effectively.

The current market-to-book ratio $\left(M / B_{t-1}\right)$ represents current market valuation of equity, which is the main contribution to the historical market-to-book ratio $\left(E F W A M B_{t-1}\right)$. Throughout Table 5, both the coefficients of $M / B_{t-1}$ and $E F W A M B_{t-1}$ are negative and significant at $1 \%$ in all regressions. High market valuation is accompanied by more equity issues and the decrease in leverage, and vice versa. The evidences confirm the market timing on the SEOs in Chinese market, although the state ownership control and non-tradable reform dilute the market timing effect in some extent. 
Amongst other variables, the effect of profitability $(E B I T D A / T A)$ on leverage is very large and significantly negative. The negative effect of profitability on leverage is well known empirical regularity in empirical literature using the US data that runs contrary to the predictions of trade off theory of capital structure ${ }^{6}$. It is therefore interesting to observe this relationship in the Chinese market as well. The coefficient of LogSale is also positive indicating that, to the extent that the size of the firm is proxied by sale, leverage ratios are positively related to size. Our results are also consistent with earlier evidences of Chinese capital structure determinants in the literature, e.g. Huang and Song (2006) and Qian et al. (2009). Overall, the results in table 5 show that historical market valuations have significant effect on the capital structure of Chinese firms. In addition, the state ownership is likely to have been divested in response to market valuations and reform policies.

\subsection{Alternative historical market-to-book ratios}

In order to obtain a robustness test, similar to Mahajan and Tartagoulu (2009), we repeat the leverage regressions utilising their alternate measures of historical market-to-book ratios: EQUITYWMB and EQUALWMB. The EQUITYWMB ratio is computed using weights in equation (1) for equity only, thus avoiding the problems of the $E F W A M B$ if the equity issues were relatively less frequent than debt issues. In similar vein, the EQUALWMB uses equal weights for debt and equity issues and thus captures the simple-average effect of the historical market-to-book ratios and thus captures dynamic balancing of capital structure changes (Kayhan \& Titman, 2007).

We replace $E F W A M B$ with $E Q U I T Y W M B$ and $E Q U A L W M B$ respectively in equation 4 to tabulate the regression results in Table 6. The results in Panel A show that the estimates of the both EQUITYWMB and $M / B_{t-1}$ are negative and significantly at conventional levels. Nonetheless, the estimates of EQUITYWMB in book leverage regression become less significance at some extent. This pattern holds when equal weighted historical average EQUALWMB ratio is used in the analysis in panel $\mathrm{B}$,. More importantly, our interaction

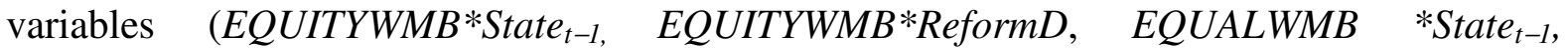
$E Q U A L W M B *$ ReformD) continue to be negative but become insignificant in several regressions. Overall, the results in the robustness tests using alternative historical market-tobook ratios are consistent with our prior main results.

\subsection{Cumulative leverage changes and the persistent effect of market timing.}

In our analyses so far we have documented that the high market valuations are associated with a decrease in leverage because of market timing on new equity issues. State controlling firms and firms in their non-tradable share reform years have less effectiveness in market timing over the new equity offerings. Moreover, we are noted that initially to maintain ownership control, state holds the largest proportion of non-tradable shares. State controlling firms are most likely the firms to implement non-tradable share reform in a mandated period. Although market timing is initiated at both government and firms' levels, the effectiveness of market timing for SOEs in new equity issuance combined with liquidating non-tradable shares should be less persistent than sole secondary equity offerings which provides longer time and opportunity for firms to capture timing (Baker \& Wurgler, 2002) In order to examine the persistency and pervasiveness effect of market timing in general we employ

\footnotetext{
${ }^{6}$ See Frank and Goyal (2009) for a discussion of the effects of firm characteristics on capital structure.
} 
regressions on cumulative leverage change. Our tests use a modified Baker and Wurgler (2002) model of Equation 6 into following form:

$$
\begin{aligned}
& \left(\frac{D}{T A}\right)_{t}-\left(\frac{D}{T A}\right)_{F i r s t}=\alpha+\beta_{1} E F W A M B_{t-1}+\beta_{2} E F W A M B_{t-1} * \text { factor } \\
& \quad+\beta_{3}\left(\frac{M}{B}\right)_{t-1}+\beta_{4}\left(\left(\frac{P P E}{T A}\right)_{t-1}+\beta_{5}\left(\frac{E B I T D A}{T A}\right)_{t-1}+\beta_{6} \log (\text { Sales })_{t-1}\right. \\
& \quad+\beta_{7}\left(\frac{D}{T A}\right)_{\text {First }}+e_{t}
\end{aligned}
$$

Because we test the market timing of new equity offerings, all are events after IPOs, the dependent variable is the cumulative change in leverage from the first year after IPO to the reporting year, which is different from Baker and Wurgler (2002) cumulative change in leverage since pro-IPO. To capture the cumulative change in leverage accurately from the first year after IPO, we use the subsample of firms that have IPOs from 2000 to 2010. Therefore the cumulative change in leverage is calculated as First +3 , First +5 , First +7 , and First +9 respectively, either in book value or market value.

The same as in model 4, we include interactive variable EFWMBAt-1 *factor that here is $E F W M B A_{t-1} *$ Statet $1^{*}$ ReformD. Because the majority of non-tradable shareholder is state, this variable is for the test on the persistence of market timing effect over state controlled firms in their particular non-tradable state share reform period. The non-negative estimate of $E_{W W B A_{t-1}} *$ Statet $-1^{*}$ ReformD is an evidence of less persistence of market timing effect on the leverage change from new equity financing for the state controlled firms in their nontradable share reform years.

Table 7 shows the regressions of cumulative changes in book and market leverage using model 5. For a robust comparison, we also arrange the regression results using a model by excluding the interaction variable from model 5. The regression excluding interaction variable is similar to that of Baker and Wurgler (2002) except for a difference that our cumulative leverage change is from the first year after IPO versus the pro-IPO year. It can be known from the regression results on the book value of cumulative leverage change in Panel A. The estimates of EFWMBA $A_{t-1}$ in specifications (1), (3), (5) and (7) are all negative and at $1 \%$ significance, which is consistent with Baker and Wurgler (2002) results for U.S. market. Overall, the effect of market timing of secondary equity offerings is persistent on the leverage change of Chinese listed firms. The estimates of the $E F W M B A_{t-1}$ in specifications (2), (4), (6) and (8) are all negative and at $1 \%$ significance as well. However, the estimates of interactive variables of $E F W M B A_{t-1} *$ Statet- $^{*}$ ReformD are positive except one in IPO+9. Also it is marginal significant in IPO+5. All of the results support our conjecture that the effectiveness of market timing for SOEs in the period of their liquidating non-tradable shares is less persistent.

The regression results on the market value of cumulative leverage change in Panel $\mathrm{B}$ look like no meaningful difference from those of Panel A. The estimates of the $E F W M B A_{t-1}$ are negative and significant at $1 \%$ except for two in IPO+3. The estimates of $E F W M B A_{t-1} *$ Statet$1 *$ Reform $D$ are positive but insignificant for all specifications. Because the non-tradable share reform is mandatory and is designed to be completed in a short period, the effectiveness of market timing for state controlled firms is less persistent than non-state controlled firms in sole new equity offerings, where firms have more relative flexibility in choosing time. 


\subsection{Market timing as a motivation for equity offerings}

The analyses presented so far establish a relation between the historical market book ratios and the decision in new equity issuance, particular, for the state controlling firms and firms in the years to complete non-tradable shares perform. In this section we examine this issue further and more directly by tracing the proceeds of share issues and to their usage in an analytical framework similar to that of Kim and Weisbach (2008), who estimate the uses of proceeds from a large sample of equity offerings. The decision of a secondary equity issue, after the initial public offerings, is presumably due to financing deficit generated by the firm's investment decision. However, if a firm's stock is overvalued, managers have incentives to take advantage of the market condition, the firm's investment requirements notwithstanding. To the extent that high market-to-book ratios points to the presence of growth opportunities in the stock price (rather than misvaluation or timing opportunities), we should expect proceeds from share issues associated with high $M / B$ ratios go to fund future investments. Alternately, if high $M / B$ ratios, as a result of mispricing, lead to equity issues, we expect the proceeds to be used for discretionary purposes such as build-up of cash reserves.

The above argument regarding the motivation for new equity offerings (market timing versus investment requirement) requires us to make a distinction between equity offerings and other sources of funds. If the market timing rationale is the overriding reason for the state agencies to issue equity, then the use of proceeds for such equity issues towards discretionary expenditures will be relatively higher as compared to proceeds from non-equity offerings. Alternately, if firms primarily use equity capital to fund investments, then we should be able to predict changes in investments uses following the equity capital raisings (Pagano, Panetta \& Zingales, 1998; Kim \& Weisbach, 2008). We measure changes in four accounting variables from the balance sheet and cash flow statements and match them to funds available from equity and non-equity sources. The accounting variables are: (1) cumulative changes in long term debt $\sum L T D e b t$, (2) changes in cash holdings $\triangle$ Cash, (3) cumulative changes in capital expenditures $\sum C A P E X$, and (4) changes in inventory $\triangle I N V$. The first two variables measure possible discretionary uses of funds (other than direct investment needs) while the last two variables are intended to capture possible ways in which the proceeds are invested in real assets.

The changes in these variables are scaled by the total assets available at a benchmark date $(\mathrm{t}=0)$. For balance sheet items (cash and inventory), the changes are measured annually as ' $Y$ ' as follows.

$$
Y=\log \left[\frac{V_{t}-V_{0}}{T A_{0}}+1\right]
$$

where $V_{t}$ stands for cash and inventory, alternately. $T A_{0}$ is the total assets in the year immediately after the IPO and $t$ is the number of years after 0 . The effect of outliers are minimised by $\log$ transformation. For the measures that are obtained from cash flow and income statement (reduction in long term debt and capital expenditure), we use the log plus the accumulation in each variable while normalising by $T A_{0}$.

$$
Y=\log \left[\left(\sum_{i=2}^{t} \frac{V_{i}}{T A_{0}}\right)+1\right]
$$


To gauge the relative influence of sources of funds from equity offerings versus non-equity capital raisings on subsequent uses of capital, we employ a specification similar to Kim and Weisbach (2008) that allows a distinction between the two. Further, this regression approach allows us to estimate marginal changes in uses of funds given a $\$ 1$ change in new capital infusion. Chinese firms are prohibited to issue shares during the first year after the IPO, our measurement of proceeds of capital issues and changes in accounting variables start at the second year following IPO and measured for four years thereafter (i.e., $t=2,3,4$ and 5). For each of these years, we designate 'eqt' as the ratio of new capital from equity offerings to $T A_{0}$ and 'oth' as the corresponding ratio of incremental capital from all other sources to $T A_{0}{ }^{7} \mathrm{We}$ then create three binary ownership variables that interact with these sources. To create the binary interacting variables, we first sort the sample by state ownership ratio in each year and then place them in three equal sized tercile groups to create three dummy variables $(L O$, $M E D$ and $H I$ ) indicating whether the firm is in the low ownership, the medium state ownership, or the high state ownership group, respectively. These three dummy variables interact with capital sources designated as 'eqt' or 'oth'. Specifically, for each of our four measures of possible uses of capital $(Y)$, we estimate

$$
\begin{aligned}
Y= & \alpha+\beta_{1} \ln (1+e q t) \cdot L O+\beta_{2} \ln (1+\text { oth }) \cdot L O \\
& +\beta_{3} \ln (1+e q t) \cdot M E D+\beta_{4} \ln (1+\text { oth }) \cdot M E D \\
& +\beta_{5} \ln (1+e q t) \cdot H I+\beta_{6} \ln (1+\text { oth }) \cdot H I \\
& +\beta_{7} L O+\beta_{8} H I+\beta_{9} \ln (T A)_{0}+\sum_{i=2001}^{t=2010} \theta_{i} \text { year dummy }+\varepsilon
\end{aligned}
$$

To test this proposition, we construct a subsample of firms that have IPOs in our main sample period from 2001 to 2010. Therefore, we are able to measure cumulative changes in capital allocation precisely from the first year after IPOs to a certain year. Since some firms have no capital raisings through SEO or other methods in a particular year, the number of firm-year observations is shrunk and less than previous analyses.

Table 8 reports estimates of equation (6), omitting $\beta_{7}$ through $\beta_{9}$ and the calendar year fixedeffects for the sake of brevity. This table shows two dimensions of uses in comparison: (1) differences in the ownership levels of firms in low, medium and high state ownership groups, and (2) differences in the sources of capital between equity ('eqt') and non-equity ('oth') offerings. The estimates in Table 7 imply that, when funds are sourced from equity issues, high state ownership firms use more capital to pay down the debt, build up cash holdings and spend less towards capital expenditures and inventory as compared to low state ownership firms. For example, coefficients on the capital raised in equity offerings are generally higher than the corresponding coefficients for other sources of capital in the equations estimating changes in cash. (For the low ownership category $(L O)$, the estimates for $\Delta$ Cash for all the years ( $\mathrm{t}=2,3,4$ and 5$)$ are higher when the dependent variable is equity funding (i.e., column marked $\ln (1+e q t) * L O)$ ) as compared to other sources (column marked $\ln (1+o t h) * L O)$ ). This evidence suggests that the new capital raised via equity is more likely to be saved as cash. In order to interpret these coefficients more meaningfully in economic terms, we provide marginal effects of these estimates in Panel B of Table 6 and discuss them below.

In Panel B, following Kim and Weisbach (2008), we calculate the effects of new capital by calculating the implied change across all four uses from the regression estimates of Panel A

\footnotetext{
${ }^{7}$ We compute total source of funds as the sum of funds from operations, sale of plants and other assets, new debt issues and equity issues. We subtract equity issues from total funds to obtain funds from other sources.
} 
that sheds a more useful economic insight on these estimates. High state ownership firms appear to spend $\$ 0.028, \$ 0.004$ and $\$ 0.015$ for each dollar of equity financing at $t=2,3$ and 5 years, respectively, as compared to $\$ 0.024, \$ 0.002$ and $\$ 0.014$ for the low state ownership firms for the corresponding periods. The p-values for the differences in the coefficient estimates are also statistically significant at five precent significance level. For change in cash holdings, both high and low state ownership groups appear to build up cash reserves more when the capital is sourced from equity offerings as compared to non-equity offerings. However, this difference is more pronounced for high state ownership firms. For example, the difference between marginal implied dollars between equity and non-equity offerings for cash holdings in $\mathrm{t}=2$ is $\$ 0.237$ ( $\$ 0.310$ vs. $\$ 0.073$ ) for the high state ownership firms as compared to the corresponding difference of $\$ 0.200$ (\$0.223 vs. $\$ 0.023$ ) for low state ownership firms. These differences are even more when compared over longer time periods of $\mathrm{t}=3,4$ and 5 . In addition, the estimates imply that for each $\$ 1$ raised via equity offerings, low state ownership firms spend more funds towards capital expenditure $\left(\sum C A P E X\right)$ and inventory $(\triangle I N V)$ than do high state ownership firms. For example, except for $\mathrm{t}=2$, the marginal dollar spent towards capital expenditure via equity financing is lower during each of the time periods for high state ownership firms as compared to the implied expenditures for low state ownership firms. Similarly, the high state ownership firms appear to spend less toward inventory.

Overall, these results suggest that the state ownership levels and the source of capital are related to category of uses of funds. High state ownership firms appear to use the proceeds from equity offerings to channel towards discretionary usage while low state ownership firms are likely to use the proceeds for investment purposes. This finding coincides to the argument that state controlled firms can easily access bank loans for investment than non-state counterparty, and state controlled firms have less incentive to raise equity capital via market timing.

\section{Conclusion}

The market timing hypothesis of Baker and Wurgler (2002) suggests that historical valuations (as measured by weighted average of historical market-to-book ratio) have significant explanatory power of capital structure determination of corporations. We apply this hypothesis to Chinese publically listed firms in privatization process which has significantly altered China's economy from being a state dominated enterprise system to robust private capital market.

In this paper we posit and provide evidence that the new equity offerings of Chinese listed firms are linked to opportunistic times when market valuations were high. We find that market timing is a general practice for Chinese listed firms to raise capital through new equity offerings. However, the effectiveness of market timing is weak for state controlling firms. The possible explanation is that state controlling firms have the advantage to access bank loans whenever they request, which reduce the incentive to finance equity by market timing.

Furthermore, firms implementing non-tradable share reform also have low effectiveness of market timing in equity financing. Because non-tradable share reform is a mandated policy that has been implemented in a short period, not only the chance of market timing is minimal, but also liquidating non-tradable shares suppresses share price. 
Finally, considering the fact that state controlling firms are the largest non-tradable shareholders and thus have to implement non-tradable share reform in required years, we examine the persistency and pervasiveness effect of market timing for those firms. Evidences show that the effect of market timing is indeed less persistent and pervasive for the state controlling firms in the years of their liquidating non-tradable shares.

Our further evidences concerning capital uses show state ownership levels and the source of capital are related to category of uses of funds. High state ownership firms appear to use the proceeds from equity offerings to channel towards discretionary usage while low state ownership firms are likely to use the proceeds for investment purposes. 


\section{References}

Allen, F., Jun Qian, and Meijun Qian, 2005, Law, finance, and economic growth in china, Journal of Financial Economics 77, 57-116. http://dx.doi.org/10.1016/j.jfineco.2004.06.010

Baker, M. and J. Wurgler, 2002, Market timing and capital structure, The Journal of Finance $57,1-32$.

http://dx.doi.org/10.1111/1540-6261.00414

Bo, H., Z. Huang and C. Wang, 2011, Understanding seasoned equity offerings of Chinese firms, Journal of Banking \& Finance 35, 1143-1157.

http://dx.doi.org/10.1016/j.jbankfin.2010.09.025

Chang, X. and S. Dasgupta, 2009, Target behavior and financing: How conclusive is the evidence?, Journal of Finance 64, 1767-1796. http://dx.doi.org/10.1111/j.1540-6261.2009.01479.x

Chen, L. and X. Zhao, 2007, Mechanical mean reversion of leverage ratios, Economics Letters 95, 223-229. http://dx.doi.org/10.1016/j.econlet.2006.10.008

Chen, Z. and P. Xiong, 2001, Discounts on illiquid stocks: evidence from China, Yale ICF Working Paper, No. 00-56, September.

Ding, S. and C. Graham, 2007, Accounting and the reduction of state-owned stock in china, Critical Perspectives on Accounting 18, 559-580. http://dx.doi.org/10.1016/j.cpa.2006.02.006

Fama, E. F. and K. R. French, 2000, Testing tradeoff and pecking order predictions about dividends and debt, Working paper, University of Chicago.

Frank, M. Z. and V. K. Goyal, 2009, Capital structure decisions: Which factors are reliably important?, Financial Management 38, 1-37. http://dx.doi.org/10.1111/j.1755-053X.2009.01026.x

Green, S., 2003, China's Stock Market: Eight Myths and Some Reasons to be Optimistic, The Royal Institute of International Affairs, Cambridge University.

Huang, G. and F. M. Song, 2006, The determinants of capital structure: Evidence from china, China Economic Review 17, 14-36.

http://dx.doi.org/10.1016/j.chieco.2005.02.007

Kayhan, A. and S. Titman, 2007, Firms' histories and their capital structures, Journal of Financial Economics 83, 1-32. http://dx.doi.org/10.1016/j.jfineco.2005.10.007

Kim, W. and M. S. Weisbach, 2008, Motivations for public equity offers: an international perspective, Journal of Financial Economics, 87. 281-307. http://dx.doi.org/10.1016/j.jfineco.2006.09.010

Li, K., T. Wang, Y. L. Cheung and P. Jiang, 2011, Privatization and risk sharing: evidence from the split share reform in China, Review of Financial Studies 24. 2499-2525. http://dx.doi.org/10.1093/rfs/hhr025

Loughran, Tim, Jay R. Ritter, and Kristian Rydqvist, 1994, Initial public offerings: International insights, Pacific-Basin Finance Journal 2, 165-199. http://dx.doi.org/10.1016/0927-538X(94)90016-7

Mahajan, A. and S. Tartaroglu, 2008, Equity market timing and capital structure: International evidence, Journal of Banking and Finance 32, 754-766. http://dx.doi.org/10.1016/j.jbankfin.2007.05.007

Pagano, M., F. Panetta and L. Zingales, 1998, Why do companies go public? An empirical analysis, Journal of Finance 53, 27-64.

http://dx.doi.org/10.1111/0022-1082.25448 
Qian, Y., Y. Tian and T. S. Wirjanto, 2009, Do chinese publicly listed companies adjust their capital structure toward a target level?, China Economic Review 20, 662-676. http://dx.doi.org/10.1016/j.chieco.2009.06.001

Rajan, R. G., and L. Zingales, 1995, What do we know about capital structure? Some evidence from international data, The Journal of Finance 50, 1421-1460. http://dx.doi.org/10.1111/j.1540-6261.1995.tb05184.x

Tian, L. and S. Estrin, 2008, Retained state shareholding in Chinese public listed companies: Does government ownership always reduce corporate value?, Journal of Comparative Economics 36, 74-89.

http://dx.doi.org/10.1016/i.jce.2007.10.003

Welch, I., 2004, Capital Structure and Stock Returns. Journal of Political Economy 112(1), 106-131. http://dx.doi.org/10.1086/379933

$\mathrm{Xu}, \mathrm{X}$. N. and Y. Wang, 1999, Ownership structure and corporate performance in Chinese stock companies, China Economic Review 10, 75-98. http://dx.doi.org/10.1016/S1043-951X(99)00006-1

Zou, H. and J. Z. Xiao, 2006, The financing behaviour of listed Chinese firms, The British Accounting Review 38, 239-258. http://dx.doi.org/10.1016/j.bar.2006.04.008 
Table 1: Summary statistics

This table presents the annual summary statistics of variables used. The sample consists of firms listed on the Chinese stock market from 2001 to 2010 . Book leverage, $(D / T A)_{b o o k}$, is defined as debt divided by total assets. Debt is defined as total assets minus book equity. Book equity is total assets minus total liabilities and preferred stock plus deferred taxes. Market leverage, $(D / T A)_{\text {market }}$, is debt divided by market value of assets (total assets minus book equity plus market value of equity). $M / B$ is market value of total assets divided by book value of total assets. $E F W A M B$ is external finance weighted average market-to-book ratio, calculated using equation (1) in text. $E Q U I T Y W M B$ is equity weighted average market-to-book ratio that is calculated by using only equity issue (e) weights in equation (1). $E Q U A L W M B$ is equal weighted average market-tobook ratio that is calculated by using only equal weights in equation (1). EBITDA is earnings before interest, taxes, depreciation and amortization. PPE is net property and plant plus equipment. LogSale is the logarithm of revenue. StateRatio is the number of state shares divided by total number of shares outstanding. TradeRatio is the number of tradeable shares divided by total number of shares outstanding. If a firm's IPO occurs during the sample period, the firm-year observations of our sample include observations from the first fiscal year after IPO to the survival year or 2010. If a firm's IPO occurs before the sample period, the firm-year observations are from 2001 to the survival year or 2010. Total number of firm-years is 10299.

\begin{tabular}{|c|c|c|c|c|c|c|c|}
\hline & Mean & S.D. & $5 \%$ & $25 \%$ & Median & $75 \%$ & $95 \%$ \\
\hline$(D / T A)_{b o o k}$ & 0.4908 & 0.1804 & 0.1762 & 0.3647 & 0.5014 & 0.6249 & 0.7692 \\
\hline$(D / T A)_{\text {market }}$ & 0.3037 & 0.1833 & 0.0554 & 0.1553 & 0.2743 & 0.4292 & 0.6410 \\
\hline$M / B$ & 2.1638 & 1.7579 & 0.9849 & 1.2963 & 1.7579 & 2.5718 & 4.8527 \\
\hline$E F W A M B$ & 3.4695 & 2.4476 & 1.2777 & 1.8069 & 2.5627 & 4.0775 & 12.0000 \\
\hline EQUITYWMB & 3.3417 & 2.2751 & 1.2951 & 1.8432 & 2.5498 & 3.8944 & 12.0000 \\
\hline EQUALWMB & 2.4753 & 1.1644 & 1.2398 & 1.6641 & 2.1629 & 2.9456 & 4.7568 \\
\hline EBITDA/TA & 0.0624 & 0.0794 & -0.0653 & 0.0358 & 0.0612 & 0.0975 & 0.1782 \\
\hline$P P E / T A$ & 0.2988 & 0.1849 & 0.0285 & 0.1592 & 0.2725 & 0.4254 & 0.6351 \\
\hline LogSale & 9.0306 & 0.6330 & 8.0724 & 8.6510 & 9.0132 & 9.3887 & 10.1064 \\
\hline StateRatio & 0.2653 & 0.2539 & 0.0000 & 0.0000 & 0.2488 & 0.4920 & 0.6800 \\
\hline TradeRatio & 0.5558 & 0.2320 & 0.2610 & 0.3763 & 0.4967 & 0.6980 & 1.0000 \\
\hline
\end{tabular}




\section{Table 2: Leverage and sources of financing}

This table reports mean and standard deviation (in parenthesis) of book leverage, market leverage, net debt issues, net equity issues and change in retained earnings from 2001 to 2010. Debt $(D)$ is defined as total assets minus book equity. Book equity is total assets minus total liabilities and preferred stock plus deferred taxes. Book leverage, $D / T A_{b o o k}$, is defined as debt divided by total assets. Market leverage, $D / T A_{\text {market }}$, is debt divided by market value of assets (total assets minus book equity plus market value of equity). Net equity issue $(e / T A)$ is the change in book equity minus the change in retained earnings divided by total assets. $\Delta R E / T A$ is the change in retained earnings divided by total assets. Net debt issue $(d / T A)$ is residual change in assets divided by total assets. Our sample consists of the firms listed on the Chinese stock market during the sample period from 2001 to 2010. If a firm's IPO occurs during the sample period, the firm-year observations of our sample include observations from the first fiscal year after IPO to the survival year or 2010. If a firm's IPO occurs before the sample period, the firm-year observations are from 2001 to the survival year or 2010.

\begin{tabular}{|c|c|c|c|c|c|c|c|c|c|c|c|}
\hline \multirow{3}{*}{$\begin{array}{l}\text { Year } \\
2001\end{array}$} & \multirow{3}{*}{$\begin{array}{r}\mathrm{N} \\
672\end{array}$} & \multicolumn{2}{|c|}{$D / T A_{b o o k}$} & \multicolumn{2}{|c|}{$D / T A_{\text {market }}$} & \multicolumn{2}{|c|}{$d / T A$} & \multicolumn{2}{|c|}{$e / T A$} & \multicolumn{2}{|c|}{$\triangle R E / T A$} \\
\hline & & Mean & S.D & Mean & S.D & Mean & S.D & Mean & S.D & Mean & S.D \\
\hline & & 0.4428 & 0.1727 & 0.1981 & 0.1178 & 0.0412 & 0.1681 & 0.042 & 0.1015 & -0.0124 & 0.0781 \\
\hline 2002 & 809 & 0.4519 & 0.1724 & 0.2470 & 0.1412 & 0.0510 & 0.1538 & 0.0186 & 0.0732 & 0.0035 & 0.0712 \\
\hline 2003 & 898 & 0.4632 & 0.1784 & 0.2989 & 0.1596 & 0.0662 & 0.1494 & 0.0238 & 0.0591 & 0.0198 & 0.0533 \\
\hline 2004 & 964 & 0.4865 & 0.1752 & 0.3623 & 0.1728 & 0.0652 & 0.1498 & 0.0205 & 0.0598 & 0.0093 & 0.0711 \\
\hline 2005 & 1015 & 0.5037 & 0.1788 & 0.4281 & 0.1884 & 0.0458 & 0.1444 & 0.0020 & 0.0742 & 0.0087 & 0.0859 \\
\hline 2006 & 1099 & 0.5084 & 0.1789 & 0.3585 & 0.1825 & 0.0466 & 0.1631 & 0.0183 & 0.0647 & 0.0115 & 0.0464 \\
\hline 2007 & 1089 & 0.5051 & 0.1752 & 0.2100 & 0.1317 & 0.0722 & 0.1518 & 0.0488 & 0.1018 & 0.0310 & 0.0561 \\
\hline 2008 & 1167 & 0.5039 & 0.1813 & 0.3888 & 0.1932 & 0.0372 & 0.1665 & 0.0139 & 0.0983 & 0.0121 & 0.0542 \\
\hline 2009 & 1274 & 0.4998 & 0.1844 & 0.2489 & 0.1614 & 0.0658 & 0.1427 & 0.0312 & 0.0697 & 0.0215 & 0.0451 \\
\hline 2010 & 1312 & 0.5053 & 0.1870 & 0.2679 & 0.1862 & 0.0836 & 0.1243 & 0.0334 & 0.0782 & 0.0268 & 0.0375 \\
\hline All & 10299 & 0.4908 & 0.1804 & 0.3037 & 0.1833 & 0.0586 & 0.1628 & 0.0252 & 0.0823 & 0.0148 & 0.0766 \\
\hline
\end{tabular}


Ma \& Rath | Market Timing of New Equity Offerings: China

Table 3: Market-timing variables and movements of Chinese stock markets

This table reports the market timing related variables and the movements of the Chinese stock market from 2001 to $2010 . M / B$ is market value of total assets divided by book value of assets. $E F W A M B$ is external finance weighted average market-to-book ratio, calculated using equation (1) in the text. StateRatio is the number of state shares divided by total number of shares outstanding. TradeRatio is the number of tradeable shares divided by total number of shares outstanding.

\begin{tabular}{|c|c|c|c|c|c|c|c|c|c|c|c|c|c|c|c|}
\hline \multirow[b]{3}{*}{ Year } & \multirow[b]{3}{*}{ No. } & \multicolumn{2}{|c|}{$M / B$} & \multicolumn{2}{|c|}{$E F W A M B$} & \multicolumn{2}{|c|}{ StateRatio } & \multicolumn{2}{|c|}{ TradeRatio } & \multirow{2}{*}{\multicolumn{3}{|c|}{$\begin{array}{l}\text { Shanghai (SSE) } \\
\text { Composite Index }\end{array}$}} & \multirow{2}{*}{\multicolumn{3}{|c|}{$\begin{array}{l}\text { Shenzhen (SZS) } \\
\text { Component Index }\end{array}$}} \\
\hline & & & & & & & & & & & & & & & \\
\hline & & Mean & S.D & Mean & S.D & Mean & S.D & Mean & S.D & $\begin{array}{l}\text { Year } \\
\text { End }\end{array}$ & $\begin{array}{l}\text { Month } \\
\text { Average }\end{array}$ & $\begin{array}{r}\text { Monthly } \\
\text { S.D }\end{array}$ & $\begin{array}{l}\text { Year } \\
\text { End }\end{array}$ & $\begin{array}{l}\text { Month } \\
\text { Average }\end{array}$ & $\begin{array}{r}\text { Monthly } \\
\text { S.D }\end{array}$ \\
\hline 2001 & 672 & 2.7153 & 1.2289 & 3.8007 & 2.2892 & 0.3198 & 0.2621 & 0.4044 & 0.1290 & 1646 & 1941 & 204 & 3326 & 4186 & 636 \\
\hline 2002 & 809 & 2.2222 & 1.0662 & 3.7086 & 2.3661 & 0.3279 & 0.2647 & 0.4005 & 0.1240 & 1358 & 1561 & 109 & 2759 & 3153 & 234 \\
\hline 2003 & 898 & 1.7936 & 0.7343 & 3.4202 & 2.3979 & 0.3772 & 0.2561 & 0.4029 & 0.1224 & 1497 & 1468 & 69 & 3480 & 3223 & 154 \\
\hline 2004 & 964 & 1.5149 & 0.5788 & 3.1980 & 2.3811 & 0.3735 & 0.2553 & 0.4040 & 0.1218 & 1267 & 1468 & 156 & 3068 & 3466 & 315 \\
\hline 2005 & 1015 & 1.3020 & 0.4807 & 2.9693 & 2.2758 & 0.3576 & 0.2520 & 0.4201 & 0.1251 & 1161 & 1145 & 68 & 2864 & 2938 & 215 \\
\hline 2006 & 1099 & 1.7142 & 0.9176 & 2.9603 & 2.2910 & 0.3031 & 0.2303 & 0.4996 & 0.1347 & 2675 & 1687 & 396 & 6647 & 4329 & 975 \\
\hline 2007 & 1089 & 3.1125 & 1.5895 & 3.2373 & 2.2688 & 0.2696 & 0.2212 & 0.5758 & 0.1527 & 5262 & 4329 & 1064 & 17701 & 13782 & 4320 \\
\hline 2008 & 1167 & 1.5091 & 0.6929 & 3.2827 & 2.3699 & 0.2353 & 0.2203 & 0.6318 & 0.1883 & 1821 & 2913 & 944 & 6486 & 10327 & 3640 \\
\hline 2009 & 1274 & 2.6102 & 1.3005 & 3.3156 & 2.3034 & 0.1304 & 0.2082 & 0.7587 & 0.2472 & 3277 & 2737 & 455 & 13700 & 10812 & 2274 \\
\hline 2010 & 1312 & 2.6512 & 1.5357 & 3.3228 & 2.2242 & 0.0934 & 0.1861 & 0.8164 & 0.2374 & 2808 & 2796 & 215 & 12459 & 11631 & 1127 \\
\hline
\end{tabular}




\section{Table 4: Determinants of annual leverage changes}

This table presents aggregated estimates from the Fama-Macbeth annual regressions from 2001 to 2010. $\left[(D / T A)_{t}-(D / T A)_{t-1}\right]$ is the change in book leverage. $D / T A$ is the book leverage defined as debt divided by total assets $(T A)$. Debt $(D)$ is defined as total assets minus book equity. Book equity is total assets minus total liabilities and preferred stock plus deferred taxes. Net equity issues $(e / T A)$ is the change in book equity minus the change in retained earnings divided by total assets. $\triangle R E / T A$ is the change in retained earnings divided by total assets. $[(E t-1)(1 / T A t-1-1 / T A t-1)]$ is the residual change in leverage. $M / B$ is market value of total assets divided by book value of assets. PPE is net property and plant plus equipment. LogSale is logarithm of revenue. EBITDA is earnings before interest, taxes, depreciation and amortization. t-statistics are in parentheses. '***', '**' and ' $*$ ' represent $1 \%, 5 \%$ and $10 \%$ statistical significance, respectively.

Dependent variable $\quad\left(\frac{D}{T A}\right)_{t}-\left(\frac{D}{T A}\right)_{t-1} \quad-\left(\frac{e}{T A}\right)_{t} \quad-\left(\frac{\Delta R E}{T A}\right)_{t} \quad-\left[E_{t-1}\left(\frac{1}{A_{t}}-\frac{1}{A_{t-1}}\right)\right]$

(1)
(2)

0.0174

(1.07)

$-0.0064 * * *$

$-(5.64)$

0.0005

$(0.16)$

(3)

(4)

\begin{tabular}{|c|c|c|c|c|}
\hline \multirow[t]{2}{*}{ Intercept } & 0.0239 & 0.0174 & 0.0246 & -0.0178 \\
\hline & $(0.91)$ & $(1.07)$ & $(0.99)$ & $-(0.69)$ \\
\hline \multirow[t]{2}{*}{$M / B_{t-l}$} & $-0.0041 * * *$ & $-0.0064 * * *$ & $-0.0019 *$ & $0.0042 * * *$ \\
\hline & $-(6.65)$ & $-(5.64)$ & $-(1.69)$ & $(6.8)$ \\
\hline \multirow[t]{2}{*}{$P P E / T A_{t-1}$} & $-0.0129 * *$ & 0.0005 & $0.0107 *$ & $-0.0249 * * *$ \\
\hline & $-(2.40)$ & $(0.16)$ & (1.89) & $-(3.96)$ \\
\hline \multirow[t]{2}{*}{$E B I T D A / T A_{t-1}$} & $-0.0824 * * *$ & $-0.1747 * * *$ & $-0.1780 * * *$ & $0.2713 * * *$ \\
\hline & $-(3.89)$ & $-(3.37)$ & $-(6.82)$ & $(4.52)$ \\
\hline \multirow[t]{2}{*}{ LogSale $_{t-1}$} & $0.0070 * * *$ & 0.0009 & -0.0023 & $0.0085 * * *$ \\
\hline & $(2.80)$ & $(0.39)$ & $-(0.83)$ & $(2.68)$ \\
\hline \multirow[t]{2}{*}{$D / T A_{t-l}$} & $-0.120 * * *$ & $-0.0475 * * *$ & $-0.0120 * * *$ & $-0.0625 * * *$ \\
\hline & $-(21.25)$ & $-(5.84)$ & $-(2.73)$ & $-(6.99)$ \\
\hline Observation & 10299 & 10299 & 10299 & 10299 \\
\hline Adjusted $\mathrm{R}^{2}$ & 0.0610 & 0.0509 & 0.0412 & 0.0945 \\
\hline
\end{tabular}




\section{Table 5: Determinants of leverage and state ownership}

This table presents aggregated estimates from the Fama-Macbeth annual regressions from 2001 to 2010. Book leverage, $D / T A_{b o o k}$ is defined as debt divided by total assets. Debt is defined as total assets minus book equity. Book equity is total assets minus total liabilities and preferred stock plus deferred taxes. Market leverage, $D / T A_{\text {market }}$, is debt divided by market value of assets (total assets minus book equity plus market value of equity). $M / B$ is market value of total assets divided by book value of total assets. $E F W A M B$ is external finance weighted average market-to-book ratio, which is calculated using equation (1). EBITDA is earnings before interest, taxes, depreciation and amortization. PPE is net property and plant plus equipment. LogSale is the logarithm of revenue. State is a binary variable that is equal to 1 if the state is the largest owner of the firm and the state ownership is larger than $30 \%$, otherwise is zero. ReformD is a binary variable that is equal tol for the years when a firm started non-tradable share reform to end of completion, otherwise is zero. t-statistics are in parentheses. '***', '**' and '*' represent $1 \%, 5 \%$ and $10 \%$ statistical significance, respectively.

$$
(D / T A)_{b o o k, t}(D / T A)_{\text {market }, t}
$$
(1)
(2)
(3)
(4)
(5)
(6)

\begin{tabular}{|c|c|c|c|c|c|c|}
\hline \multirow[t]{2}{*}{ Intercept } & $-0.1429^{*}$ & $-0.1590 * *$ & $-0.1546^{* *}$ & $-0.3640 * * *$ & $-0.3693 * * *$ & $-0.3815^{* * *}$ \\
\hline & $-(1.68)$ & -(1.96) & $-(1.81)$ & $-(5.84)$ & $-(5.93)$ & $-(6.25)$ \\
\hline \multirow[t]{2}{*}{$E F W A M B_{t-1}$} & $-0.0113 * * *$ & $-0.0097 * * *$ & $-0.0120 * * *$ & $-0.0137 * * *$ & $-0.0135^{* * *}$ & $-0.0114 * * *$ \\
\hline & $-(4.95)$ & $-(5.00)$ & $-(4.84)$ & $-(22.30)$ & $-(16.18)$ & $-(12.64)$ \\
\hline \multirow{2}{*}{$\begin{array}{l}\text { EFWAMB }_{t-1} \\
\text { State }_{t-1}\end{array}$} & & $-0.0031 *$ & & & $-0.0004 *$ & \\
\hline & & $-(1.66)$ & & & $(-1.74)$ & \\
\hline \multirow{2}{*}{$\begin{array}{l}\text { EFWAMB }{ }_{t-1} \\
* \text { ReformD }\end{array}$} & & & $-0.0044^{*}$ & & & $-0.0065^{*}$ \\
\hline & & & $-(1.87)$ & & & $-(1.91)$ \\
\hline \multirow[t]{2}{*}{$M / B_{t-1}$} & $-0.0091 * *$ & $-0.0095^{* *}$ & $-0.0095 * *$ & $-0.0343 * * *$ & $-0.0340 * * *$ & $-0.0329 * * *$ \\
\hline & $-(2.40)$ & $-(2.11)$ & $-(2.22)$ & $-(10.27)$ & $-(10.75)$ & $-(12.31)$ \\
\hline \multirow[t]{2}{*}{$P P E / T A_{t-1}$} & $-0.0531 * * *$ & $-0.0503 * * *$ & $-0.0443 * * *$ & -0.0318 & -0.0312 & -0.0321 \\
\hline & $-(2.97)$ & $-(2.94)$ & $-(4.23)$ & $-(1.39)$ & $-(1.41)$ & $-(1.44)$ \\
\hline \multirow[t]{2}{*}{$E B I T D A / T A_{t-l}$} & $-0.9005 * * *$ & $-0.8984 * * *$ & $-0.8996 * * *$ & $-0.6529 * * *$ & $-0.6499 * * *$ & $-0.6419 * * *$ \\
\hline & $-(8.75)$ & $-(8.56)$ & $-(8.70)$ & $-(9.61)$ & $-(9.43)$ & -(9.90) \\
\hline \multirow[t]{2}{*}{ LogSale $_{t-1}$} & $0.0863 * * *$ & $0.0880 * * *$ & $0.0877 * * *$ & $0.0928 * * *$ & $0.0933 * * *$ & $0.0950 * * *$ \\
\hline & $(9.87)$ & (10.66) & (10.11) & (16.37) & (16.51) & (17.70) \\
\hline Observation & 10299 & 10299 & 10299 & 10299 & 10299 & 10299 \\
\hline Adjusted $\mathrm{R}^{2}$ & 0.2533 & 0.2579 & 0.2591 & 0.3301 & 0.3314 & 0.3325 \\
\hline
\end{tabular}




\section{Table 6: Alternate measures of market timing}

This table presents aggregated estimates from the Fama-Macbeth annual regressions from 2001 to 2010. Book leverage, $(D / T A)_{b o o k}$, is defined as debt divided by total assets. Debt is defined as total assets minus book equity. Book equity is total assets minus total liabilities and preferred stock plus deferred taxes. Market leverage, $(D / T A)_{\text {market }}$, is debt divided by market value of assets (total assets minus book equity plus market value of equity). $M / B$ is market value of total assets divided by book value of total assets. EQUITYWMB is equity weighted average market-to-book ratio that is calculated by using only equity issue $(e)$ weights in equation (1). EQUALWMB is equal weighted average market-to-book ratio that is calculated by using only equal weights in equation (1). EBITDA is earnings before interest, taxes, depreciation and amortization. PPE is net property and plant plus equipment. LogSale is the logarithm of revenue. State is a binary variable that is equal to 1 if the state is the largest owner of the firm and the state ownership is larger than $30 \%$, otherwise is zero. ReformD is a binary variable that is equal tol for the years when a firm started non-tradable share reform to end of completion, otherwise is zero. t-statistics are in parentheses. ' $* * *$ ', ' $* *$ ' and '*' represent $1 \%, 5 \%$ and $10 \%$ statistical significance, respectively.

Panel A: EQUITYWMB

\begin{tabular}{|c|c|c|c|c|c|c|}
\hline & \multicolumn{3}{|c|}{$(D / T A)_{b o o k, t}$} & \multicolumn{3}{|c|}{$(D / T A)_{\text {market }, t}$} \\
\hline & (1) & (2) & (3) & (4) & $(5)$ & (6) \\
\hline \multirow[t]{2}{*}{ Intercept } & $-0.3345 * * *$ & $-0.3501 * * *$ & $-0.3371 * * *$ & -0.4856 *** & $-0.49213 * * *$ & $-0.4990 * * *$ \\
\hline & $-(4.94)$ & $-(5.48)$ & $-(4.74)$ & $-(8.29)$ & $-(8.62)$ & $-(8.73)$ \\
\hline \multirow[t]{2}{*}{$E Q U I T Y W M B_{t-1}$} & $-0.0015^{*}$ & $-0.0030^{*}$ & $-0.0026^{*}$ & $-0.0064 * * *$ & $-0.0061 * * *$ & $-0.0044 * * *$ \\
\hline & $-(1.67)$ & $-(1.89)$ & $-(1.71)$ & $-(9.31)$ & $-(5.56)$ & $-(4.46)$ \\
\hline \multirow[t]{2}{*}{$E_{\text {EUITYWMB }}$ State $_{t-1}$} & & -0.0001 & & & -0.0010 & \\
\hline & & $-(0.43)$ & & & $-(1.33)$ & \\
\hline \multirow[t]{2}{*}{ EQUITYWMB*ReformD } & & & -0.0002 & & & $-0.0015^{*}$ \\
\hline & & & $-(1.11)$ & & & $-(1.87)$ \\
\hline \multirow[t]{2}{*}{$M / B_{t-1}$} & $-0.0174 * *$ & $-0.0178 * * *$ & $-0.0180 * * *$ & $-0.0390 * * *$ & $-0.0390 * * *$ & $-0.0405^{* * *} *$ \\
\hline & $-(2.97)$ & $-(3.04)$ & $-(2.92)$ & $-(11.16)$ & $-(11.36)$ & $-(11.05)$ \\
\hline \multirow[t]{2}{*}{$P P E / T A_{t-1}$} & $-0.0498 * * *$ & $-0.0470 * * *$ & $-0.0508 * * *$ & -0.0279 & -0.0277 & $-0.0258^{*}$ \\
\hline & $-(2.65)$ & $-(2.60)$ & $-(2.67)$ & $-(1.33)$ & $-(1.35)$ & $-(1.84)$ \\
\hline \multirow[t]{2}{*}{$E B I T D A / T A_{t-1}$} & $-0.9115 * * *$ & $-0.9193 * * *$ & $-0.9136 * * *$ & $-0.6780^{* * * *}$ & $-0.6770 * * *$ & $-0.6688 * * *$ \\
\hline & $-(8.77)$ & $-(8.76)$ & $-(12.73)$ & $-(9.91)$ & $-(9.83)$ & $-(10.13)$ \\
\hline \multirow[t]{2}{*}{$\operatorname{logSale}_{t-1}$} & $0.1040 * * *$ & $0.1057 * * *$ & $0.1048 * * *$ & $0.1046^{* * *}$ & $0.1053^{* * *}$ & $0.1073 * * *$ \\
\hline & (14.87) & (14.05) & (14.45) & (20.12) & (20.75) & (21.20) \\
\hline Observation & 10299 & 10299 & 10299 & 10299 & 10299 & 10299 \\
\hline Adjusted $\mathrm{R}^{2}$ & 0.2325 & 0.2363 & 0.2371 & 0.3069 & 0.3086 & 0.3079 \\
\hline
\end{tabular}


$(D / T A)_{b o o k, t}$

(7) (8) (9)

Intercept

$\begin{array}{lll}-0.2670^{* * *} & -0.2808^{* * * *}-0.2706^{* * * *}\end{array}$

$-(3.49)$

$-(3.87)$

$-(3.46)$

$-0.00713 * * \quad-0.0045^{* *}$

$-0.0098 * *$

$-(2.34)$

$-(1.98)$

$-(2.71)$

EQUALWMB * State $_{t-1}$

$-0.0032 *$

$-(1.68)$

EQUALWMB *ReformD

$E B I T D A / T A_{t-1}$

$\operatorname{logSale}_{t-1}$

Observation

Adjusted R ${ }^{2}$

$0.0017 *$

$\begin{array}{ccc}-0.8989 * * * & -0.9001 * * * & -0.8968 * * * \\ -(8.29) & -(8.22) & -(8.28)\end{array}$

$\begin{array}{lll}10299 & 10299 & 10299 \\ 0.2498 & 0.2512 & 0.2566\end{array}$

$(10) \quad(11)$

$\begin{array}{lll}-0.3743 * * * & -0.3786^{* * *} & -0.3547 * * *\end{array}$

$-0.0011$

$-(1.28)$ $-0.0104 * *$ $0.0274^{* * * *}$ $-(7.17)$ $-0.0351^{*}$ $-(1.75)$ $-(1.56)$

$$
-(1.75)
$$

$-0.6491 * * *$
$-(9.13)$

$-0.6491 * * * \quad-0.6263 * * *$

$0.0954 * * * 0.0957 * * * \quad 0.0953 * * *$

\begin{tabular}{|c|c|c|c|c|}
\hline (12.79) & (13.67) & (12.59) & (19.52) & (20.06) \\
\hline
\end{tabular}

10299

10299

10299

0.3329

0.3328 


\section{Table 7: Determinants of cumulative changes in leverage}

This table reports the results from regressions with dependent variable being cumulative change in leverage over 3, 5, 7 and 9-year periods for firms listed on the Chinese stock markets. 'First' refers to the first instance of the leverage available in the sample. Book leverage, $(D / T A)_{\text {book }}$, is defined as debt divided by total assets. Debt is defined as total assets minus book equity. Book equity is total assets minus total liabilities and preferred stock plus deferred taxes. Market leverage, $(D / T A)_{\text {market }}$, is debt divided by market value of assets (total assets minus book equity plus market value of equity). 'First' refers to the first instance of the leverage available in the sample. $M / B$ is market value of total assets divided by book value of total assets. EFWAMB is external finance weighted average market-to-book ratio, which is calculated using equation (1). EBITDA is earnings before interest, taxes, depreciation and amortization. PPE is net property and plant plus equipment. LogSale is the logarithm of revenue. State is a binary variable that is equal to 1 if the state is the largest owner of the firm and the state ownership is larger than $30 \%$, otherwise is zero. ReformD is a binary variable that is equal to 1 for the years 2005 and onward, otherwise is zero. t-statistics are in parentheses. '***', '**' and '*' represent $1 \%, 5 \%$ and $10 \%$ statistical significance, respectively.

Panel A: Book Leverage

$$
\left(\frac{D}{A}\right)_{b o o k, t}-\left(\frac{D}{A}\right)_{b o o k, f i r s t}
$$

\begin{tabular}{ccccccccc}
\hline \multicolumn{3}{c}{$\mathrm{IPO}+3$} & \multicolumn{3}{c}{$\mathrm{IPO}+5$} & $\mathrm{IPO}+7$ & \multicolumn{3}{c}{$\mathrm{IPO}+9$} \\
$(1)$ & $(2)$ & $(3)$ & $(4)$ & $(5)$ & $(6)$ & $(7)$ & $(8)$ \\
\hline $0.2158^{* * * *}$ & $0.2188^{* * *}$ & -0.0850 & -0.0496 & -0.0832 & -0.0492 & -0.2670 & $-0.2927^{*}$ \\
$(2.80)$ & $(2.83)$ & $(-0.73)$ & $(-0.42)$ & $(-0.61)$ & $(-0.36)$ & $(-1.62)$ & $(-1.75)$
\end{tabular}

$E F W A M B_{t-1}$ $\begin{array}{llllll}-0.0081 * * *-0.0085 * * * & -0.0210 * * *-0.0227 * * * & -0.0229 * * * & -0.0275 * * *-0.0335 * * *-0.0305 * * *\end{array}$

$$
\begin{array}{llllll}
(-3.62) \quad(-3.75) \quad(-6.38) \quad(-6.66) \quad(-5.96) \quad(-5.50) \quad(-7.43)
\end{array}
$$

$\operatorname{EFWAM}_{t-1} *$

State $_{t-1} *$ ReformD

State

$(M / B)_{t-1}$

${ }^{(P P E / T A)^{t-1}}$

$(\text { EBITDA/TA })_{t-1}$

(EBITA/TA)

(logSale $_{t-1}$

Obs

Adjusted $\mathrm{R}^{2}$

\subsection{2}

(1.06)

$-0.0065$

$-0.0062$

$(-1.48)$

$(-1.41)$

$-0.0025$

$0.0070^{*}$

0.0059

(1.85)

(1.43)

$-0.0443 * *$

(-1.96)

$-0.0457 * *$

$(-0.44)$

$-0.0028$

0.0028

$(-0.50)$

(0.48)

0.004

(0.81)

$0.0217 * * *$

(2.73)

$-0.0054$

$-0.0112$

0.0331

$0.0299 \quad-0.0477$

$-0.0489$

$(-2.02) \quad(-0.17)$

$(-0.36)$

(0.87)

(0.78)

$(-0.98)$

$(-1.01)$

$-0.2700$

$-0.2746$

$6-0.8672$

$$
(-3.45)^{* * *}(-3.50)^{* * *} \quad(-8.93)
$$

$(-8.83)$

$(-9.03)$

$(-9.07)$

$(-6.33)$

$-0.8239 * * *$

$$
-0.0009
$$

$-0.0013$

$0.0564 * * *$

$0.0519 * * *$

$0.0603 * * *$

$0.0567 * * *$

$0.0826^{* * * *}$

$0.0859 * * *$

$(-0.10)$

$(-0.14)$

(4.18)

(3.79)

(3.97)

(3.69)

(4.56)

(4.69)

$-0.1905 * * *-0.1912 * * *-0.5037 * * *-0.4909 * * *$

$$
(-6.18)
$$

$$
(-6.20)
$$$$
(-12.78)
$$

$(-12.30)$

$(-12.49)$

$-0.5930 * * *$

$-0.5977 * * *-0.6040 * * *$

655

490

373

$(-12.48)$

$(-9.53)$

$(-9.59)$

0.0986

\begin{abstract}
0.1084
\end{abstract}

\begin{abstract}
0.3509
\end{abstract}
0.3541

0.3950

0.3968

0.4356

251

$-0.0055$

$(-6.31)$ 


\begin{tabular}{|c|c|c|c|c|c|c|c|c|}
\hline & & & & $\left(\frac{D}{A}\right)_{\text {market }, t}$ & $-\left(\frac{D}{A}\right)_{\text {market }, f}$ & first & & \\
\hline & IPO & +3 & IPO & +5 & IPO & +7 & IPO & +9 \\
\hline & (1) & (2) & (3) & (4) & (5) & (6) & (7) & (8) \\
\hline Intercept & $0.2569 * *$ & $0.2483 * *$ & 0.2613 & 0.2782 & 0.0466 & 0.0745 & -0.2494 & -0.2406 \\
\hline & $(2.38)$ & (2.30) & (1.42) & (1.49) & $(0.28)$ & $(0.43)$ & $(-1.30)$ & $(-1.24)$ \\
\hline$E F W A M B_{t-1}$ & -0.0012 & -0.0055 & $-0.0154 * * *$ & $-0.0162 * * *$ & $-0.0178 * * *$ & $-0.021 * * * 6$ & $-0.0326 * * *$ & $-0.0336 * * *$ \\
\hline & $(-0.37)$ & $(-1.02)$ & $(-2.94)$ & $(-2.98)$ & $(-3.74)$ & $(-3.47)$ & $(-6.24)$ & $(-5.49)$ \\
\hline$E F W A M B_{t-1} *$ & & & & & & & & \\
\hline State $_{t-1} *$ ReformD & & 0.0037 & & 0.0033 & & 0.0049 & & 0.0019 \\
\hline & & (1.14) & & $(0.55)$ & & $(0.94)$ & & $(0.33)$ \\
\hline$(M / B)_{t-1}$ & $-0.0283 * * *$ & $-0.0293 * * *$ & $-0.0295 * * *$ & $-0.0297 * * *$ & $-0.0266 * * *$ & $-0.0249 * * *$ & 0.0127 & 0.0135 \\
\hline & $(-4.58)$ & $(-4.74)$ & $(-3.31)$ & $(-3.33)$ & $(-3.65)$ & $(-3.31)$ & $(1.38)$ & $(1.41)$ \\
\hline$(P P E / T A)_{t-1}$ & -0.0522 & -0.0481 & -0.0119 & -0.0146 & 0.0104 & 0.0078 & -0.0132 & -0.0127 \\
\hline & $(-1.65)$ & $(-1.52)$ & $(-0.24)$ & $(-0.30)$ & $(0.22)$ & $(0.16)$ & $(-0.23)$ & $(-0.23)$ \\
\hline$(E B I T D A / T A)_{t-1}$ & $-0.2888 * * *$ & $-0.2755^{* * *} *$ & $-0.7945^{* * *}$ & $-0.7894 * * *$ & $-0.7758 * * *$ & $-0.7794 * * *$ & $-0.5113 * * *$ & -0.5122 \\
\hline & $(-2.63)$ & $(-2.52)$ & $(-5.14)$ & $(-5.10)$ & $(-5.70)$ & $(-5.73)$ & $(-3.38)$ & $(-3.38) * * *$ \\
\hline$\left(\right.$ logSale $_{t-1}$ & -0.0036 & -0.0025 & 0.0198 & 0.0176 & $0.0412 * *$ & $0.0383 * *$ & $0.0617 * * *$ & $0.0606 * * *$ \\
\hline & $(-0.28)$ & $(-0.20)$ & $(0.92)$ & $(0.81)$ & (2.19) & $(2.00)$ & $(2.95)$ & $(2.85)$ \\
\hline$(D / A)_{\text {first }}$ & $-0.1759 * * *$ & $-0.1738 * * *$ & $-0.4284 * * *$ & $-0.4223 * * *$ & $-0.4384 * * *$ & $-0.4372 * * *$ & -0.1148 & -0.1126 \\
\hline & $(-4.07)$ & $(-4.03)$ & $(-6.83)$ & $(-6.63)$ & $(-7.41)$ & $(-7.38)$ & $(-1.58)$ & $(-1.54)$ \\
\hline Obs & 65 & & 45 & 90 & 37 & 73 & 25 & 51 \\
\hline Adjusted $\mathrm{R}^{2}$ & 0.0771 & 0.0837 & 0.1862 & 0.1850 & 0.2481 & 0.2479 & 0.2282 & 0.2253 \\
\hline
\end{tabular}




\section{Table 8: The effect of new equity and ownership on subsequent usage of capital}

This table reports the effect of new sources of funds categorized from secondary equity offerings and other capital on subsequent changes in assets and expenditures of Chinese listed firms, which is specified in equation (6) in text. $\sum L T D e b t$ is the cumulative change in long term debt. $\triangle$ Cash is the changes in cash holding. $\sum C A P E X$ is the cumulative change in capital expenditures. $\triangle I N V$ is the change in inventory. The eqt represents new capital from secondary equity offerings and oth represents new capital from other source, both of which are normalized by total assets. LO, MED, and HI represent low, middle and high level of state ownership each year respectively. The following variables are included in all regressions but not reported: Year fixed effects, $\log$ (total assets), LO, and HI. Panel A presents coefficients and t-stats using heteroskedasticity consistent standard errors clustered by industry. Panel B presents the implied change in the dependent variables when equity capital (eqt) or other sources (oth) funds is increased by one dollar for each ownership group and p-values from comparing coefficients. Bold letters indicate statistical significance at the 5\% level. The sample is the firms that have IPOs in the period from 2001 to 2010.

Panel A: Regression estimates

\begin{tabular}{|c|c|c|c|c|c|c|c|c|c|}
\hline & $\mathrm{t}$ & $\mathrm{N}$ & $\begin{array}{l}\ln (1+e q t)^{*} \\
L O\end{array}$ & $\begin{array}{l}\ln (1+o t h) * \\
L O\end{array}$ & $\begin{array}{l}\ln (1+e q t)^{*} \\
M E D\end{array}$ & $\ln (1+o t h) * M E D$ & $\begin{array}{l}\ln (1+e q t)^{*} \\
H I\end{array}$ & $\ln (I+o t h) * H I$ & $R^{2} \quad$ Adj- \\
\hline \multirow[t]{4}{*}{$\begin{array}{l}\sum L T \text { Debt } \\
\text { Reduction }\end{array}$} & 2 & 267 & $\begin{array}{l}0.0455 \\
(0.79)\end{array}$ & $\begin{array}{r}0.3693 \\
(7.80)\end{array}$ & $\begin{array}{r}-0.0038 \\
(-0.05)\end{array}$ & $\begin{array}{r}0.5370 \\
(8.46)\end{array}$ & $\begin{array}{c}0.1623 \\
(0.82)\end{array}$ & $\begin{array}{r}0.3880 \\
(6.92)\end{array}$ & 0.3927 \\
\hline & 3 & 222 & $\begin{array}{l}0.0054 \\
(0.10)\end{array}$ & $\begin{array}{l}0.2646 \\
(6.12)\end{array}$ & $\begin{array}{r}-0.2042 \\
(-3.07)\end{array}$ & $\begin{array}{r}0.5667 \\
(9.14)\end{array}$ & $\begin{array}{l}0.1013 \\
(1.07)\end{array}$ & $\begin{array}{r}0.4847 \\
(7.93)\end{array}$ & 0.3635 \\
\hline & 4 & 213 & $\begin{array}{l}-0.0099 \\
(-0.12)\end{array}$ & $\begin{array}{l}0.4722 \\
(7.58)\end{array}$ & $\begin{array}{l}-0.4607 \\
(-4.56)\end{array}$ & $\begin{array}{l}1.2391 \\
(18.07)\end{array}$ & $\begin{array}{l}-0.4036 \\
(-1.96)\end{array}$ & $\begin{array}{l}0.7790 \\
(8.57)\end{array}$ & 0.6356 \\
\hline & 5 & 208 & $\begin{array}{l}0.0278 \\
(0.22)\end{array}$ & $\begin{array}{l}0.5150 \\
(7.52)\end{array}$ & $\begin{array}{r}-0.5766 \\
(-4.47)\end{array}$ & $\begin{array}{l}1.0677 \\
(10.30)\end{array}$ & $\begin{array}{l}0.1389 \\
(0.77)\end{array}$ & $\begin{array}{l}0.6874 \\
(10.16)\end{array}$ & 0.4856 \\
\hline \multirow[t]{4}{*}{$\Delta$ Cash } & 2 & 267 & $\begin{array}{l}0.6517 \\
(4.84)\end{array}$ & $\begin{array}{l}0.1324 \\
(1.20)\end{array}$ & $\begin{array}{l}0.7070 \\
(4.03)\end{array}$ & $\begin{array}{l}0.2296 \\
(1.56)\end{array}$ & $\begin{array}{l}1.5007 \\
(3.26)\end{array}$ & $\begin{array}{l}0.1454 \\
(1.11)\end{array}$ & 0.2101 \\
\hline & 3 & 222 & $\begin{array}{l}1.2197 \\
(10.31)\end{array}$ & $\begin{array}{l}0.4670 \\
(4.93)\end{array}$ & $\begin{array}{l}0.8922 \\
(6.13)\end{array}$ & $\begin{array}{l}0.2501 \\
(1.84)\end{array}$ & $\begin{array}{l}1.0781 \\
(5.18)\end{array}$ & $\begin{array}{l}0.2794 \\
(2.09)\end{array}$ & 0.4655 \\
\hline & 4 & 213 & $\begin{array}{r}0.5888 \\
(3.99)\end{array}$ & $\begin{array}{r}0.3068 \\
(2.74)\end{array}$ & $\begin{array}{l}1.2816 \\
(7.04)\end{array}$ & $\begin{array}{c}0.0954 \\
(0.77)\end{array}$ & $\begin{array}{l}0.5921 \\
(1.58)\end{array}$ & $\begin{array}{l}0.2409 \\
(1.47)\end{array}$ & 0.2865 \\
\hline & 5 & 208 & $\begin{array}{r}0.5497 \\
(2.88)\end{array}$ & $\begin{array}{r}0.7467 \\
(7.17)\end{array}$ & $\begin{array}{l}1.4549 \\
(7.40)\end{array}$ & $\begin{array}{l}0.1810 \\
(1.15)\end{array}$ & $\begin{array}{l}0.4364 \\
(1.59)\end{array}$ & $\begin{array}{r}0.4833 \\
(4.69)\end{array}$ & 0.4523 \\
\hline \multirow[t]{3}{*}{$\sum C A P E X$} & 2 & 267 & $\begin{array}{l}0.0749 \\
(0.63)\end{array}$ & $\begin{array}{l}0.3099 \\
(3.21)\end{array}$ & $\begin{array}{l}0.7048 \\
(4.58)\end{array}$ & $\begin{array}{l}0.4775 \\
(3.69)\end{array}$ & $\begin{array}{l}0.7635 \\
(1.89)\end{array}$ & $\begin{array}{l}0.3705 \\
(3.24)\end{array}$ & 0.1904 \\
\hline & 3 & 222 & $\begin{array}{l}0.1688 \\
(1.34)\end{array}$ & $\begin{array}{l}0.4055 \\
(4.03)\end{array}$ & $\begin{array}{l}0.1966 \\
(1.27)\end{array}$ & $\begin{array}{l}0.6579 \\
(4.56)\end{array}$ & $\begin{array}{l}0.1842 \\
(0.83)\end{array}$ & $\begin{array}{l}0.7895 \\
(5.55)\end{array}$ & 0.1716 \\
\hline & 4 & 213 & $\begin{array}{l}0.4290 \\
(2.80)\end{array}$ & $\begin{array}{l}0.6052 \\
(5.20)\end{array}$ & $\begin{array}{l}0.6615 \\
(3.50)\end{array}$ & $\begin{array}{l}0.4274 \\
(3.34)\end{array}$ & $\begin{array}{l}0.1735 \\
(0.45)\end{array}$ & $\begin{array}{l}1.0142 \\
(5.97)\end{array}$ & 0.2477 \\
\hline
\end{tabular}


Ma \& Rath | Market Timing of New Equity Offerings: China

\begin{tabular}{|c|c|c|c|c|c|c|c|c|c|}
\hline & 5 & 208 & $\begin{array}{l}0.2016 \\
(0.80)\end{array}$ & $\begin{array}{l}0.9292 \\
(6.76)\end{array}$ & $\begin{array}{r}-0.1316 \\
(-0.51)\end{array}$ & $\begin{array}{r}1.0082 \\
(4.84)\end{array}$ & $\begin{array}{l}-0.0492 \\
(-0.14)\end{array}$ & $\begin{array}{l}1.1250 \\
(8.28)\end{array}$ & 0.3209 \\
\hline \multirow[t]{4}{*}{$\Delta I N V$} & 2 & 267 & $\begin{array}{l}0.0815 \\
(0.70)\end{array}$ & $\begin{array}{l}0.4444 \\
(4.67)\end{array}$ & $\begin{array}{l}0.1811 \\
(1.19)\end{array}$ & $\begin{array}{l}0.2790 \\
(2.19)\end{array}$ & $\begin{array}{l}0.2561 \\
(0.64)\end{array}$ & $\begin{array}{l}0.1840 \\
(1.63)\end{array}$ & 0.1267 \\
\hline & 3 & 222 & $\begin{array}{l}0.3046 \\
(2.34)\end{array}$ & $\begin{array}{l}0.5424 \\
(5.20)\end{array}$ & $\begin{array}{l}0.2826 \\
(1.76)\end{array}$ & $\begin{array}{l}0.5410 \\
(3.62)\end{array}$ & $\begin{array}{l}0.0901 \\
(0.39)\end{array}$ & $\begin{array}{l}0.4455 \\
(3.02)\end{array}$ & 0.1554 \\
\hline & 4 & 213 & $\begin{array}{l}0.0578 \\
(0.27)\end{array}$ & $\begin{array}{l}0.9001 \\
(5.63)\end{array}$ & $\begin{array}{l}0.4548 \\
(1.75)\end{array}$ & $\begin{array}{c}0.6828 \\
(3.88)\end{array}$ & $\begin{array}{l}-0.1194 \\
(-0.22)\end{array}$ & $\begin{array}{l}0.5057 \\
(2.17)\end{array}$ & 0.1505 \\
\hline & 5 & 208 & $\begin{array}{l}-0.1201 \\
(-0.41)\end{array}$ & $\begin{array}{l}1.2052 \\
(7.46)\end{array}$ & $\begin{array}{l}1.0735 \\
(3.52)\end{array}$ & $\begin{array}{l}0.4759 \\
(1.96)\end{array}$ & $\begin{array}{c}0.5344 \\
(1.25)\end{array}$ & $\begin{array}{r}0.8304 \\
(5.20)\end{array}$ & 0.2851 \\
\hline
\end{tabular}

Panel B: Implied dollar changes and p-values from t-tests

\begin{tabular}{|c|c|c|c|c|c|c|c|c|c|c|c|c|}
\hline & \multirow[b]{3}{*}{$\mathrm{t}$} & \multirow[b]{3}{*}{$\mathrm{N}$} & \multicolumn{6}{|c|}{ Implied \$ Change } & \multicolumn{4}{|c|}{ p-Values $\left(\mathrm{H}_{0}: \beta_{\mathrm{i}}=\beta_{\mathrm{j}}\right)$} \\
\hline & & & \multicolumn{2}{|c|}{$L O$} & \multicolumn{2}{|c|}{$M E D$} & \multicolumn{2}{|c|}{$H I$} & \multirow{2}{*}{$\begin{array}{c}L O \\
\left(\beta_{1} \text { vs. } \beta_{2}\right)\end{array}$} & \multirow{2}{*}{$\begin{array}{c}H I \\
\left(\beta_{5} \text { vs. } \beta_{6}\right)\end{array}$} & \multirow{2}{*}{$\begin{array}{c}\text { Eqt. } \\
\left(\beta_{1} \text { vs. } \beta_{5}\right)\end{array}$} & \multirow{2}{*}{$\begin{array}{c}\text { Oth. } \\
\left(\beta_{2} \text { vs. } \beta_{6}\right)\end{array}$} \\
\hline & & & Eqt & Oth & Eqt & Oth & Eqt & Oth & & & & \\
\hline \multirow{4}{*}{$\begin{array}{l}\sum L T \text { Debt } \\
\text { Reduction }\end{array}$} & 2 & 267 & 0.024 & 0.171 & 0.001 & 0.050 & 0.028 & 0.054 & 0.00 & 0.00 & 0.00 & 0.00 \\
\hline & 3 & 222 & 0.002 & 0.095 & -0.022 & 0.055 & 0.004 & 0.031 & 0.00 & 0.00 & 0.00 & 0.00 \\
\hline & 4 & 213 & -0.007 & 0.095 & -0.019 & 0.056 & -0.036 & 0.054 & 0.00 & 0.00 & 0.00 & 0.00 \\
\hline & 5 & 208 & 0.014 & 0.080 & -0.039 & 0.066 & 0.015 & 0.044 & 0.00 & 0.00 & 0.00 & 0.00 \\
\hline \multirow[t]{4}{*}{$\Delta$ Cash } & 2 & 267 & 0.223 & 0.023 & 0.073 & 0.026 & 0.310 & 0.073 & 0.00 & 0.00 & 0.00 & 0.27 \\
\hline & 3 & 222 & 0.077 & 0.023 & 0.106 & 0.028 & 0.505 & 0.167 & 0.00 & 0.00 & 0.00 & 0.00 \\
\hline & 4 & 213 & 0.064 & 0.017 & 0.064 & 0.010 & 0.182 & 0.061 & 0.00 & 0.00 & 0.85 & 0.00 \\
\hline & 5 & 208 & 0.045 & 0.033 & 0.107 & 0.011 & 0.123 & 0.116 & 0.00 & 0.05 & 0.00 & 0.00 \\
\hline \multirow[t]{4}{*}{$\sum C A P E X$} & 2 & 267 & 0.054 & 0.174 & 0.090 & 0.054 & 0.157 & 0.066 & 0.00 & 0.00 & 0.00 & 0.00 \\
\hline & 3 & 222 & 0.132 & 0.196 & 0.041 & 0.086 & 0.010 & 0.072 & 0.00 & 0.00 & 0.36 & 0.00 \\
\hline & 4 & 213 & 0.171 & 0.212 & 0.072 & 0.036 & 0.044 & 0.116 & 0.00 & 0.00 & 0.00 & 0.00 \\
\hline & 5 & 208 & 0.102 & 0.254 & -0.016 & 0.141 & 0.019 & 0.122 & 0.00 & 0.00 & 0.00 & 0.00 \\
\hline \multirow[t]{4}{*}{$\Delta I N V$} & 2 & 267 & 0.055 & 0.199 & 0.022 & 0.029 & 0.046 & 0.028 & 0.00 & 0.05 & 0.00 & 0.00 \\
\hline & 3 & 222 & 0.168 & 0.192 & 0.042 & 0.051 & 0.011 & 0.032 & 0.00 & 0.00 & 0.00 & 0.00 \\
\hline & 4 & 213 & 0.042 & 0.184 & 0.037 & 0.034 & -0.012 & 0.039 & 0.00 & 0.00 & 0.00 & 0.00 \\
\hline & 5 & 208 & -0.006 & 0.193 & 0.097 & 0.031 & 0.056 & 0.054 & 0.00 & 0.00 & 0.00 & 0.00 \\
\hline
\end{tabular}

